\title{
Do Growth-Option Firms Use Less Relative Performance Evaluation?
}

\author{
Ana Albuquerque \\ Boston University School of Management \\ Católica-Lisbon School of Business and Economics \\ albuquea@bu.edu
}

March 25, 2013

\begin{abstract}
The use of relative performance evaluation (RPE) in compensation contracts for CEOs at growth-option (GO) firms that operate in more volatile environments can provide insurance against common exogenous shocks and thus reduce the amount of risk that CEOs face. However, the implementation of RPE for high GO firms can be impaired by these firms' inability to find a peer group that captures common risk exposure. This paper studies GO firms' reliance on RPE and finds that the use of RPE in CEO compensation contracts varies negatively with a firm's level of growth options. The tests use three proxies for growth options: the market-to-book value of assets, research and development expenses scaled by assets, and a factor obtained from a principal component analysis. The results are robust to controlling for the impact of other firm characteristics on pay-for-performance sensitivities.
\end{abstract}

Keywords: Relative performance evaluation, CEO compensation, growth options.

Data Availability: All data are obtained from publicly available sources.

This paper is based on the second chapter of my dissertation at the University of Rochester titled "Essays on Relative Performance Evaluation." I would especially like to thank the editor Harry Evans and two anonymous referees as well as Jim Brickley, Krish Menon, Ross Watts, and Jerry Zimmerman for many helpful comments and suggestions. I am also grateful for comments from Rui Albuquerque, Mary Ellen Carter, Lei (Tony) Chen, Liz Demers, Fabrizio Ferri, Andy Leone, Philip Joos, Claudine Mangen, Michael Raith, Eddie Riedl, Nathan Stuart, Joanna Wu, Tina Zamora, seminar participants at Boston University, the 2005 Fall Junior Faculty Conference at Yale, the 2006 American Accounting Association Annual Meeting, and the 2008 Financial Accounting and Reporting Section. I acknowledge financial support from the Foundation for Science and Technology. All errors are my own. E-mail: albuquea@bu.edu. 


\section{INTRODUCTION}

Chief executive officers (CEOs) of firms with more growth opportunities tend to operate in more volatile environments. The use of relative performance evaluation (RPE) in compensation contracts for CEOs of growth-option (GO) firms can provide insurance against common exogenous shocks to firm performance and thus reduce the amount of risk that CEOs face. However, these firms' use of RPE also can be impaired by the high costs associated with RPE implementation. The extent of RPE usage for high GO firms is an empirical question and the focus of this paper.

In considering the benefits of using RPE, Holmstrom $(1979,1982)$ and others show that the optimal compensation for a risk-averse executive should depend exclusively on the firm's performance that is unrelated to exogenous peer performance. Hence RPE usage is more beneficial for firms that are more exposed to common exogenous risks. The evidence discussed below suggests that firms with more growth opportunities have higher systematic risk, and that they benefit more from using RPE. This implies that the use of RPE in compensation policies can be particularly beneficial for high GO firms as a way of reducing exposure to common risks.

The extent to which RPE is useful in compensation contracts depends on the firm's ability to find a peer group whose performance is subject to the same external shocks. The usefulness of RPE for high GO firms can be limited because of the lack of peers facing common shocks. Firms that have a higher proportion of assets represented by growth options expect to earn future abnormal economic rents through the existence of firm-specific know-how, barriers to entry, or other proprietary information (e.g., patents) that is not available to other firms. Consequently, peer group performance is a less informative measure of the common external 
shocks that affect the firm because it is more affected by each peer's idiosyncratic performance. The paper tests whether the costs of implementing RPE outweigh the benefits of its use for high versus low growth-options firms.

Using 15,557 CEO-firm observations for the sample period of 1995 to 2008, this study documents that RPE in CEO compensation contracts varies negatively with a firm's level of growth options. I use as proxies for a firm's level of GO the market-to-book value of assets, the ratio of $R \& D$ expenses to assets, and a growth-options principal component that summarizes the common information contained in the previous two proxies plus the ratio of advertising expenses to assets. The results are robust to controlling for firm characteristics, including the correlation between firm and peer performance, idiosyncratic variance, CEO tenure, industry concentration, CEO wealth, and size. The results are also consistent using either industry-size peers, or, alternatively, industry-GO peers to address concerns that high GO firms face different systematic risk and thus using other high GO firms as peers is more effective at eliminating such risk.

To further corroborate the results above, I analyze explicit evidence of RPE use. Using hand-collected data for the 2006 to 2008 period for a sample of 750 firms and their disclosure of RPE use in compensation contracts, I find that high GO firms are less likely to disclose their use of RPE and that the firms that do so rely on relatively fewer actual peers. Both findings are consistent with the hypothesis that the peer group is less informative about common shocks for these firms.

Using the paper's empirical model, I construct an implicit firm-specific measure of RPE that allows different firm characteristics, in addition to GO, to drive RPE use. I aggregate this measure to analyze the significance of RPE use across industries. The results show that the highest users of RPE are the utility, financial, and energy industries, which are low GO 
industries. The lowest users of RPE are the health care and information technology industries, which are high GO industries. This ranking shows that a firm's level of GO drives RPE use even after controlling for other firm characteristics.

This paper contributes to the compensation literature by providing evidence that a firm's level of RPE use in implicit compensation contracts is negatively related to its level of growth options. There is little prior evidence linking RPE use to a firm's level of growth options. Gerakos et al. (2007) and Carter et al. (2008) analyze the disclosure of performance-based conditions in equity grants and find some evidence that the market-to-book ratio is negatively associated with the use of performance-based conditions (see also Gong et al. 2011). However, these relations may reflect differences in disclosure practices between firms with high and low market-to-book values. Murphy (2001) uses the industry levels of growth opportunities as a proxy for managers' influence activities caused by the use of internal benchmarks in compensation contracts, and hypothesizes that firms in industries with more growth opportunities are more likely to adopt external benchmarks (or RPE). Murphy finds no statistically significant association between the industry's level of GO and a firm's use of RPE.

Next, Section II develops the hypothesis to be tested. Section III presents the empirical model. Section IV describes the sample and data, and Section V presents the results. Section VI discusses alternative explanations and robustness tests. Section VII concludes.

\section{HYPOTHESIS DEVELOPMENT}

This paper studies the extent to which growth-option firms rely on RPE to insulate CEOs from common shocks outside of their control. In this section, I discuss the trade-offs associated with the use of RPE in CEO compensation contracts at these firms. 


\section{Benefits of RPE for Growth-Option Firms}

In the models of Holmstrom (1979, 1982), Diamond and Verrecchia (1982), and Holmstrom and Milgrom (1987), the optimal compensation for a risk-averse executive depends exclusively on the firm's performance that is unrelated to exogenous peer performance. This is the main premise of relative performance evaluation. Therefore, the use of RPE in compensation contracts is expected to be more beneficial for firms that are more exposed to common exogenous shocks or systematic risk because RPE alleviates unwanted risk exposure for riskaverse CEOs.

The evidence suggests that firms that derive a larger proportion of their value from future growth opportunities, rather than from assets in place, are typically exposed to more systematic risk, implying that these firms would benefit more from using RPE. Grinblatt and Titman (2001) argue that growth-option firms usually have higher market betas, because growth options are most valuable in good times and have a great deal of systematic risk. Their intuition is that "growing franchises like Starbucks, promising biotech and internet firms such as Amgen or Netscape ... with high ratios of market value of equity to book value of equity have valuable growth options. However, the systematic risk of these growth options ... depends on how strongly the growth is tied to the health of the economy. The stronger the tie to the health of the economy, the riskier the growth option" (2001, 380). Campbell and Vuolteenaho (2004) use a two-beta asset pricing model and find that growth stocks have relatively lower betas with market cash flow shocks, but much higher betas with market discount rate shocks. They conclude that growth stocks have higher overall betas with the market in the post-1963 period (see also Cohen et al. 2010). Kogan and Papanikolaou (2012) find that portfolios of firms with higher Tobin's Q 
have higher systematic risk than do portfolios of firms with lower Tobin's Q. ${ }^{1}$ Using firm-level data, Albuquerque et al. (2012) find that R\&D expenses are positively associated with market beta, conditional on other determinants of firm systematic risk.

Theory models also predict that growth-option firms have more systematic risk. For example, Gomes et al. (2003) model the factors that explain the size and book-to-market effects in stock returns and argue that their model can generate these effects under the assumption that growth-option firms have more systematic risk.

\section{Costs of RPE for Growth-Option Firms}

The implementation of RPE requires the board to decide on a peer group that can serve to benchmark the firm's performance. ${ }^{2}$ The empirical evidence cited above, which finds that growth-option firms have higher systematic risk through higher market betas, suggests a higher covariance with peer performance for these firms. However, as Holmstrom and Milgrom (1987) show, the informativeness of peer performance depends on both the covariance of firm performance with peer performance and the variance of peer performance. I argue that the estimation error of the covariance with peer performance is higher for high GO firms, as is the variance of peer performance, making the peer group a less informative measure of common external shocks for GO firms. The argument is based on the premise that these firms derive most of their value from options to make positive net-present-value investments in the future, as opposed to cash flows generated by assets in place (Myers 1977). These investments are likely to earn future economic rents that are not competed away due to firm-specific know-how, other

\footnotetext{
${ }^{1}$ This evidence is consistent with the conditional analysis in Petkova and Zhang (2005), who show that growthoption firms have higher systematic risk in good market times and lower systematic risk in bad times. Unconditionally, growth-option firms should have higher systematic risk, because good times are more likely than bad times during the sample period.

${ }^{2}$ Defining a performance measure that evaluates CEOs can be challenging in itself for high GO firms, thus limiting RPE's usefulness. Examples of the difficulty that investors have in valuing growth-option firms are the volatility of internet and biotech stocks (Schwert 2002) and the fact that analysts and researchers have focused on nontraditional financial metrics to evaluate these firms (Demers and Lev 2001).
} 
proprietary information (e.g., patents), or brand name recognition unavailable to other firms (Tirole 1988). Incumbents are therefore faced with fewer competitors or peers. In this situation, the average peer performance is relatively more affected by each peer's idiosyncratic performance and is thus a less informative measure of common shocks. Over time, patents expire and barriers to entry decline, leading to the entry of new competitors that reduce rents. Pastor and Veronesi (2003) find that firms with low market-to-book ratios are relatively more mature even after controlling for other determinants of growth options (Fama and French 2004). Thus low GO firms have more peers whose performance better captures common shocks.

The appendix provides a formal model showing that noise in the estimation of the covariance with peer performance contributes to less RPE use. In particular, the model shows that the coefficient associated with peer performance has three components. As in Holmstrom and Milgrom (1987), it depends on the sensitivity of pay to firm performance and on the correlation between firm and peer performance. In addition to these effects, the model shows that the coefficient associated with peer performance — and RPE—is negatively affected by the noise in estimating the covariance between firm and peer performance.

In a contracting framework similar to Holmstrom and Milgrom (1987), Yim (2001) analyzes the implications of contract renegotiation for executive compensation and shows that poorly informative signals lead to no RPE. If, as argued above, peer performance is a less informative signal for high GO firms, Yim's model would also predict less RPE use in these firms.

In summary, RPE can be beneficial for GO firms as a way to reduce the exposure of CEO compensation to firm risk. However, the practical difficulties in implementing RPE are more 
significant for GO firms. ${ }^{3}$ The extent to which growth-option firms rely on RPE compensation contracts is thus an empirical question.

Hypothesis: The level of RPE use in CEO compensation contracts is not associated with a firm's level of growth options.

\section{EMPIRICAL SPECIFICATION}

To test whether a firm's level of RPE use varies with growth options, I estimate the following pooled cross-sectional, time-series regression model:

$$
\begin{aligned}
\mathrm{W}_{\mathrm{it}} & =\mathrm{c}+\eta_{1} \text { Ret }_{\mathrm{it}}+\eta_{2} \operatorname{Ret}_{\mathrm{it}} \times \mathrm{GO}_{\mathrm{it}}+\eta_{3} \operatorname{Ret}_{\mathrm{pt}}+\eta_{4} \operatorname{Ret}_{\mathrm{pt}} \times \mathrm{GO}_{\mathrm{it}} \\
& +\eta \text { ControlVariables } \\
\mathrm{it}-1 & +\mathrm{Yr}_{\mathrm{t}}+\operatorname{Ind}_{\mathrm{t}}+\text { ExecId }_{\mathrm{t}}+\varepsilon_{\mathrm{it}} .
\end{aligned}
$$

The variable $\mathrm{W}_{\mathrm{it}}$ is the compensation of the CEO of firm $i$ at time $t$. The performance of firm $i$ at time $t$ is measured by its annual stock return, $\operatorname{Ret}_{\mathrm{it} .}{ }^{4}$ Following Albuquerque (2009), the peer group performance for firm $i$ at time $t, \operatorname{Ret}_{\mathrm{pt}}$, is measured by the mean annual stock return of the firms in the same industry and size quartile as that of firm $i$. Albuquerque (2009) studies the impact of different peer-group portfolios on implicit tests of RPE in CEO compensation contracts and finds consistent evidence of RPE using industry-size peer groups but not when

\footnotetext{
${ }^{3}$ There are other potential difficulties in implementing RPE. Milgrom (1988) argues that the asymmetry of information between CEOs and their boards implies that CEOs have incentives to spend time and other firm resources influencing board's compensation decisions. Arguably, to avoid these wasteful influence activities, efficiently designed compensation contracts should rely less on RPE. If peers are harder to identify for GO firms, I expect that it is in high GO firms that influence activities over the choice of peer group are more likely to occur and where RPE should be used less. However, evidence on self-serving selection of RPE peers is mixed (Carter et al. 2008; Gong et al. 2011). Dye (1992) studies how the use of RPE can affect the agent's project choice. When the agent can choose among several limited projects, RPE leads the agent to choose a project where relative performance, not absolute performance, which is the relevant performance for the principal, is the highest. This results in inappropriate project choice. To the extent that the selection of a project from a limited set of available projects is more relevant for GO firms, Dye's argument suggests that GO firms should not depend on RPE and thus avoid distortion costs associated with poor project choices.

${ }^{4}$ The results presented in the paper are qualitatively similar if accounting performance, measured by the change in return on assets, is added to the regression model. As in other studies, no evidence of RPE is found using accounting performance.
} 
using other peer groups, such as industry-based peers or S\&P 500 peers. ${ }^{5}$ The level of firm $i$ growth opportunities at time $t$ is represented by $\mathrm{GO}_{\text {it. }}$ Following Holmstrom and Milgrom (1987), Janakiraman et al. (1992), and Aggarwal and Samwick (1999a), RPE is defined by the ratio of the estimated coefficient on peer performance to the coefficient on own-firm performance and captures the relative importance of noise that is filtered out from the amount of pay at risk.

A set of control variables is included to capture any variation in the level of CEO pay that is unrelated to firm or peer performance. The control variables are discussed below. The above model is estimated with year $\left(\mathrm{Yr}_{\mathrm{t}}\right)$ and industry $\left(\mathrm{Ind}_{\mathrm{t}}\right)$ dummies to control for differences in pay levels across time and industries (Murphy 1999). CEO-fixed effects $\left(\right.$ ExecId $\left._{t}\right)$ are also included to control for differences in pay levels that are due to unobservable CEO characteristics that do not vary during the sample period. Graham et al. (2011) and Coles and Li (2010) show that the inclusion of CEO-fixed effects explains a significant portion of the variation in CEO pay and its omission can lead to biased estimates of other variables. The variable $\varepsilon_{\mathrm{it}}$ is a white-noise process uncorrelated over time or across firms. The coefficient $\eta_{1}$ is traditionally labeled as the pay-forperformance sensitivity. Smith and Watts (1992) argue that GO firms should offer higher equity incentives to their executives to overcome information asymmetries between shareholders and executives regarding managerial discretion over project choice (i.e., $\eta_{2}>0$ ). The coefficient $\eta_{3}$ is expected to be negative if a firm uses RPE, which is a test of a weak form of RPE (for a strongform version of the RPE test, see Janakiraman et al. 1992; Albuquerque 2009). This is consistent with the board filtering out some common shocks by using peer performance. The main

\footnotetext{
${ }^{5}$ Several recent studies using the 2006 SEC disclosure rules provide evidence that industry and size firm characteristics are among the two most important determinants of actual peer selection. Gong et al. (2011) analyze how firms select actual RPE peers. Bizjak et al. (2011), Faulkender and Young (2010), Cadman and Carter (2011), and Albuquerque et al. (2012) analyze how firms select peers for benchmarking purposes.
} 
hypothesis tested in this paper is whether the pay-for-peer-performance sensitivity is associated with GO $\left(\eta_{4}=0\right)$. If the net benefits derived from RPE use for firms with more growth opportunities are negative, then less RPE is used, and $\eta_{4}$ is positive. Likewise, if the net benefits from RPE use for these firms are positive, then $\eta_{4}$ is negative.

I expand the above model to allow both firm and peer performance sensitivities to vary with the firm's idiosyncratic variance (IdVar $\left.{ }_{i t}\right)$, the CEO's tenure (CEOTenure $\left.{ }_{i t}\right)$, and the firm's Herfindahl Index (HerfindahlIndex ${ }_{i t}$ ). In addition, the pay-for-peer-performance sensitivity is allowed to vary with the correlation between firm and peer performance (Correlation $\left.{ }_{\text {it }}\right)$. The expanded empirical model tested in the paper is as follows:

$$
\begin{aligned}
\mathrm{W}_{\mathrm{it}}= & \mathrm{c}+\eta_{1} \operatorname{Ret}_{\mathrm{it}}+\eta_{2} \operatorname{Ret}_{\mathrm{it}} \times \mathrm{GO}_{\mathrm{it}}+\eta_{3} \operatorname{Ret}_{\mathrm{pt}}+\eta_{4} \operatorname{Ret}_{\mathrm{pt}} \times \mathrm{GO}_{\mathrm{it}} \\
& +\eta_{5} \operatorname{Ret}_{\mathrm{it}} \times \operatorname{IdVar}_{\mathrm{it}}+\eta_{6} \operatorname{Ret}_{\mathrm{it}} \times \mathrm{CEOTenure}_{\mathrm{it}}+\eta_{7} \operatorname{Ret}_{\mathrm{it}} \times \text { HerfindahlIndex }_{\mathrm{it}} \\
& +\eta_{8} \operatorname{Ret}_{\mathrm{pt}} \times \text { Correlation }_{\mathrm{it}}+\eta_{9} \operatorname{Ret}_{\mathrm{pt}} \times \operatorname{IdVar}_{\mathrm{it}}+\eta_{10} \operatorname{Ret}_{\mathrm{pt}} \times \text { CEOTenure }_{\mathrm{it}}+\eta_{11} \operatorname{Ret}_{\mathrm{pt}} \times \text { HerfindahlIndex }_{\mathrm{it}} \\
& +\eta \text { ControlVariables }_{\mathrm{it}-1}+\mathrm{Yr}_{\mathrm{t}}+\operatorname{Ind}_{\mathrm{t}}+\text { ExecId }_{\mathrm{t}}+\varepsilon_{\mathrm{it}} .
\end{aligned}
$$

The interaction between firm performance and idiosyncratic variance, $\operatorname{Ret}_{\mathrm{it}} \times \mathrm{IdVar}_{\mathrm{it}}$, controls for the fact that firms with higher idiosyncratic risk might use relatively less incentive pay because that imposes higher unwanted risks on their CEOs $\left(\eta_{5}<0\right)$ (Holmstrom and Milgrom 1987; Aggarwal and Samwick 1999a; and Equation (3) in the appendix). The interaction between CEO tenure and firm performance is included because Gibbons and Murphy (1992) show that the sensitivity of compensation to firm performance should be stronger for CEOs who are closer to retirement as an attempt to counteract potential horizon problems $\left(\eta_{6}>0\right)$ (Dechow and Sloan 1991). Aggarwal and Samwick (1999b) find that firms in more concentrated industries, as measured by the Herfindahl index, place greater positive weight on peer performance relative to firm performance as a way to provide incentives for firms to collude. I follow Aggarwal and 
Samwick (1999b) and add an interaction term between firm performance and the Herfindahl index in the empirical model although no prediction is offered for the coefficient $\eta_{7}$.

The interaction between peer performance and correlation, $\operatorname{Ret}_{\mathrm{pt}} \times$ Correlation $_{\mathrm{it}}$, controls for the fact that RPE is more desirable to filter common shocks when peer and firm performance are more highly correlated $\left(\eta_{8}<0\right)$. The interaction between the coefficient on peer performance and the firm's idiosyncratic variance, $\operatorname{Ret}_{\mathrm{pt}} \times \operatorname{IdVar}_{\mathrm{it}}$, is expected to be positive if it captures the lower need for RPE $\left(\eta_{9}>0\right)$ when $\eta_{5}<0$. The sign on the coefficient associated with $\operatorname{Ret}_{\mathrm{pt}} \times$ CEOTenure $_{i t}$ is affected by conflicting predictions. CEOs with longer tenure would benefit from a more negative weight on peer performance if they are exposed to more firm risk through higher firm pay sensitivity $\left(\eta_{10}<0\right)$. However, Gibbons and Murphy (1990), using a model based on learning about ability, suggest that RPE is less beneficial to CEOs with longer tenures $\left(\eta_{10}>0\right)$. Gibbons and Murphy show that the manager's compensation is a function of the manager's expected ability as disclosed through firm performance. They show that RPE can be beneficial as a way to filter common risk from firm performance, thus allowing for better identification of managerial ability. Following their argument, RPE is expected to be less useful for CEOs with longer tenure, as the board's inference regarding CEO's ability from past firm performance is less noisy. The interaction between peer performance and Herfindahl Index, Ret $_{\mathrm{pt}} \times$ HerfindahlIndex $_{\mathrm{it}}$, controls for the finding in Aggarwal and Samwick (1999b) that RPE is used less in more concentrated industries $\left(\eta_{11}>0\right)$.

\section{SAMPLE SELECTION AND DESCRIPTIVE STATISTICS}

\section{Sample Selection and Data Sources}

I use the May 2009 Standard \& Poor's ExecuComp database for CEO compensation. 
This database contains data for the S\&P 1500 firms for fiscal years 1992 to 2008. Execucomp may contain a limited number of high GO firms because these are typically small growing firms that may not be included yet on the S\&P 1500 . The potential limited number of high GO firms in my sample might bias the findings towards no result. The financial data are obtained from Compustat, and the stock return data are obtained from the Center for Research in Security Prices (CRSP). The CRSP-Indexes-U.S. Treasury and Inflation are used for inflation data.

(Place Table 1 Here)

Table 1 summarizes the sample selection procedure. The initial sample consists of all Execucomp CEOs with available data on compensation and tenure. For a CEO to be included in the final sample, the CEO has to be in office at the end of the fiscal year and be the only CEO in a firm-year. I also require non-missing data on all the variables used to estimate the regression model. Following Bhojraj et al. (2003) and Boni and Womack (2006), I use the historical Global Industry Classification Standard (GICS) to group firms by industry. The GICS is available on Compustat for fiscal years starting in 1995. The GICS is designed and maintained by Standard \& Poor's and Morgan Stanley Capital International and classifies firms based on their principal business activity, measured by their source of revenues and earnings as well as the market's perception as disclosed in investment research reports. Bhojraj et al. (2003) argue that industries classified according to GICS display greater co-movement in stock returns and in various key financial ratios than industries classified by the Standard Industry Classification (SIC), the North American Industry Classification System (NAICS), and the Fama and French (1997) industry classification. Below, I discuss the robustness of the results to using the SIC or NAICS codes. To remove the effect of extreme outliers, I drop the observations that correspond to the top and 
bottom one percent of the distributions for growth options and stock returns. ${ }^{6}$ These data requirements yield a sample of 15,557 CEO-year observations from 1995 to 2008 . The sample contains 3,885 unique CEOs at 2,457 unique firms.

(Place Table 2 Here)

\section{Variable Definitions}

I briefly define the variables used in the tests. Table 2 presents detailed definitions. The CEO compensation measure used in the empirical tests is the total annual flow compensation. I measure annual performance for both the firm and its peer group using annual compounded stock returns (including dividends) from the CRSP monthly tapes. Following Albuquerque (2009), the peer group performance is the average stock return from a group of peer firms matched on industry and firm size.

I use three different proxies for growth options. One is the ratio of the market value of assets to the book value of assets. This proxy for growth options has been widely used in the literature (Smith and Watts 1992; Gaver and Gaver 1993; Bizjak et al. 1993; Baber et al. 1996). As pointed out by Smith and Watts (1992), this measure has a significant measurement error for firms with long-lived assets because assets are measured at historical cost net of depreciation. Thus I also consider other proxies for growth options.

The second proxy is the ratio of R\&D expenses to the book value of assets. Following past studies (Himmelberg et al. 1999), missing observations for R\&D expenses are assumed to be zero, because firms with negligible R\&D expenses are not required to report them separately. Eliminating observations with missing values for $R \& D$ significantly reduces the sample size to

\footnotetext{
${ }^{6}$ For example, the range of growth options defined as market-to-book value of assets lies between 0.197 and 105.09, whereas 98 percent of the observations are between 0.799 and 9.46 .
} 
about half and introduces a potential sample selection bias towards R\&D intensive firms. ${ }^{7}$ The rationale for using $\mathrm{R} \& \mathrm{D}$ expenses scaled by assets as a proxy for a firm's level of GO is that firms that invest heavily in R\&D are those that can create barriers to entry for competitors through the development of new products or technologies (Smith and Watts 1992; Gaver and Gaver 1993; Himmelberg et al. 1999). As a robustness check, I add advertising expenses to R\&D expenses because firms can also create barriers to entry using brand-name recognition. Missing observations for advertising expenses are also set to zero to avoid losing observations. The untabulated results using advertising expenses added to $R \& D$ expenses scaled by assets are qualitatively the same.

The third proxy for a firm's level of growth options is the first principal component from a principal component analysis (Gaver and Gaver 1993; Baber et al. 1996) using the market-tobook value of assets, the ratio of $R \& D$ expenses to assets, and the ratio of advertising expenses to assets. The justification for using a principal component is that it is unlikely that any single variable perfectly captures a firm's unobservable level of growth options. Principal component analysis constructs a variable that summarizes the common information among these observable variables, thus reducing measurement error. The principal component analysis produces a factor with an eigenvalue larger than one that explains 46 percent of the variation in the above variables. Although Gaver and Gaver (1993) and Baber et al. (1996) use a broader set of variables to construct a growth-option factor, I find that including more variables does not affect the main GO factor or the main results.

The variable Correlation is the slope coefficient from regressing the firm's stock return

\footnotetext{
${ }^{7}$ However, the main results are similar when observations with missing R\&D expenses are excluded.
} 
on the stock return of its peer group. ${ }^{8}$ The variable Idiosyncratic Variance is the error variance from this regression. The variable Herfindahl Index is calculated as the sum of the squared market shares for all of the firms in the same industry-size group as the firm. The control variables included in the regression model are ones that the literature has shown to influence CEO pay and are meant to control for the difference in pay levels across CEOs. CEO pay is typically higher at larger firms, as these firms require more talented managers (Rosen 1982; Smith and Watts 1992; Murphy 1999). Smith and Watts (1992) also find that firms with more growth opportunities have higher executive compensation. The inclusion of CEO tenure tries to capture any differences in the level of pay related to CEO talent, experience (Himmelberg and Hubbard 2000), or entrenchment (Bertrand and Mullainathan 2001). I use lagged values for the variables size and growth options to control for the fact that the firm characteristics might be choices of the CEO rather than exogenous variables. Firm size is measured as the natural log of sales to decrease the skewness of this variable. CEO tenure is the difference between the year the executive assumed the CEO position and the current fiscal year if the CEO is in office during the whole fiscal year. I use the log of the CEO tenure, as in Core and Guay (1999), to account for a possible concave relation between experience, measured by the tenure in the firm and the level of pay. I also include a dummy that takes the value of one when CEO tenure is negative and the executive is the CEO in office for that firm-year. ${ }^{9}$ Core et al. (1999) find that the level of CEO pay is related to the firm's strength of corporate governance, so I include governance measures to control for the possibility that CEO pay is higher when the governance structure is less effective. The governance measures include whether the CEO is the board chair, whether the CEO is

\footnotetext{
${ }^{8}$ Aggarwal and Samwick (1999a, 93) call this variable Beta. To avoid confusion with market beta, I use Correlation for the name of this variable.

${ }^{9}$ Execucomp only retains the latest date for when the executive becomes the CEO of a particular company. In cases where the executive assumed the position of CEO for the same company at a different time, the variable CEO tenure has a negative value.
} 
involved in an interlocking relationship, and the level of the CEO's share of the firm's equity.

For all measures, a high number means greater potential agency conflicts and presumably a weaker governance structure.

(Place Table 3 Here)

\section{Descriptive Statistics}

Panel A of Table 3 reports the descriptive statistics for the entire sample and for the subsamples of high and low GO firms. High (low) GO firms are defined as the firms whose level of GO, measured as the market-to-book value of assets, is in the top (bottom) tercile of the distribution of all sample firms. I first describe the characteristics of the firms analyzed by using the full sample. All variables are inflation-adjusted to 1992 dollars. The cash compensation and equity compensation average $\$ 1,223,000$ and $\$ 2,355,000$, respectively. Because total compensation is highly positively skewed, I use the log of total annual flow compensation in the empirical analysis. The median continuously compounded annual real (inflation-adjusted) stock return in the sample is 6.1 percent. The average firm has sales of $\$ 3.9$ billion and market capitalization of $\$ 6$ billion. The mean (median) level of GO measured by the ratio of the market value of assets to the book value of assets is 1.9 (1.5). The mean (median) level of GO measured by the ratio of $R \& D$ expenses to total assets is 2.3 percent (zero percent). This GO proxy is highly skewed because many firms have zero $R \& D$ expenses, such as those in the financial services. The correlation between the peer group and firm performance is 0.75 for the average firm.

Panel A of Table 3 also provides descriptive statistics for the high and low growth-option sub-samples. All of the differences in means ( $t$-test) between high and low growth-option firms are statistically significant at the $\mathrm{p}<0.01$ level, except for cash compensation and firm size 
measured by sales. The nonparametric tests on the equality of medians (chi-square test) across the high and low GO firms are rejected for all variables at the $p<0.01$ level. CEOs of high GO firms receive more equity compensation and more total pay. This univariate evidence is consistent with past studies that argue that GO firms pay a greater percentage of CEO compensation in the form of equity, such as stock options and restricted stock (e.g., Clinch 1991; Smith and Watts 1992; Bizjak et al. 1993; Gaver and Gaver 1993). Table 3 also shows that CEOs at high GO firms have longer tenures with their firms than CEOs at low GO firms (Bizjak et al. 1993, Kole 1997). ${ }^{10}$ Also, firms with more growth options have higher market capitalization, a lower level of revenues, and a lower realized firm and peer stock performance than firms with low GO. The lower realized firm return is a manifestation of the well-known value premium puzzle. High GO firms also exhibit higher idiosyncratic variance than low GO firms as previously documented by Pastor and Veronesi (2003) and Cao et al. (2008). High GO firms exhibit lower correlation between firm and peer performance than low GO firms. The mean (median) of Correlation is $0.71(0.69)$ in high GO firms, which is statistically significantly lower than the $0.79(0.78)$ in low GO firms $(\mathrm{p}<0.01)$.

The bottom of Panel A in Table 3 shows the number of firms in the peer group and the Herfindahl index, as a measure of concentration, for high and low GO firms. The mean number of firms in each peer group is lower for high GO firms than for low GO firms (9.5 versus 10.5, respectively, with the difference statistically significant at the $p<0.01$ level), suggesting that

\footnotetext{
${ }^{10}$ Bizjak et al. (1993) observe that high GO firms use longer intervals in assessing managerial performance. Kole (1997) provides evidence that the mandatory holding period for restricted stock and the average wait to exercise managerial stock options are typically longer for high growth firms. Unreported results also show that the CEOs at high GO firms in the sample are younger than their counterparts at low GO firms and the difference is statistically different at the $\mathrm{p}<0.01$ level. However, this variable is only available for about 50 percent of the total number of observations and thus is not included in the tests.
} 
growth firms are more likely to be in industries with fewer firms. ${ }^{11}$ Consistent with the argument that GO firms operate in industries with barriers to entry that enable them to have some market power and earn abnormal returns, Table 3 also shows that the mean Herfindahl index is statistically significantly higher for high GO firms-22.4 percent versus 18.8 percent for low GO firms $(\mathrm{p}<0.01)$. The univariate evidence from the number of peers and the Herfindahl index is consistent with high GO firms having noisier estimates of peer performance.

The industry breakdown of the sample firms, presented in Panel B of Table 3, shows that the two most represented industries in the sample are Capital Goods (four-digit GICS code 2010, which includes Aerospace \& Defense, Electrical Equipment, Industrial Conglomerates, and Machinery) and Materials (four-digit GICS code 1510, which includes Chemicals, Construction Materials, and Containers \& Packaging) with ten percent and eight percent of the total observations, respectively. The two least represented industries are Household \& Personal Products (four-digit GICS code 3030) and Telecommunication Services (four-digit GICS code 5010, which includes Diversified and Wireless Services) with 0.88 percent and 0.91 percent of the observations, respectively. The industries with more growth options, regardless of the GO proxy used, are Pharmaceuticals and Biotechnology (GICS 3520), Software and Services (GICS 4510), and Semiconductors and Semiconductor Equipment (GICS 4530). Those with fewer growth options are Banks (GICS 4010), Insurance (GICS 4030), Diversified Financials (GICS 4020), and Utilities (GICS 5510). The untabulated results are qualitatively similar if banks, insurance, and utilities are excluded from the analysis.

(Place Table 4 Here)

Table 4 reports the correlations between the variables used in the multivariate tests. The

\footnotetext{
${ }^{11}$ Similar results are obtained when peers are defined by firms in the same industry and GO quartile.
} 
Spearman (Pearson) correlations are reported in the upper (lower) diagonal. I discuss the Spearman correlations because the results are similar for the Pearson correlations. The correlation between firm and peer stock returns is $0.53(\mathrm{p}<0.05)$, describing the extent to which firm stock returns reflect external shocks outside the CEO's control. CEO compensation is positively associated with a firm's level of growth options when measured as the market-to-book value of assets (correlation of $0.12 ; \mathrm{p}<0.05$ ) or as the factor (correlation of $0.09 ; \mathrm{p}<0.05$ ), but is not significantly correlated with the level of R\&D expenses. The correlation between firm and peer stock returns (Correlation) is negatively related to the firm's level of growth options independently of the GO proxy used, as reflected in the correlation of -0.09 and statistically significant at the $\mathrm{p}<0.05$ level when GO are measured as the market-to-book value of assets. This cross-sectional evidence corroborates the results presented above that the mean time-series correlation between firm and peer performance is lower for GO firms, which suggests that although high GO firms are exposed to more systematic risk, it is harder for these firms to find a peer group that captures common exogenous shocks. Also, a firm's level of idiosyncratic variance seems to be positively correlated with the level of GO, as reflected in the correlation of 0.14 ; statistically significant at the $\mathrm{p}<0.05$ level when $\mathrm{GO}$ are measured as the market-to-book value of assets.

\section{EMPIRICAL RESULTS}

This section presents the main empirical results from testing how RPE use in CEO compensation contracts varies with a firm's GO level. Using the results from these estimations, I construct an implied firm-specific measure of RPE use across industries. Further, I present the results from using different peer-group definitions. 
(Place Table 5 Here)

\section{Multivariate Analysis}

Panel A of Table 5 shows the estimation results for Equations (1) and (2). Panel B presents estimates of the level of RPE use for the average firm and for high and low GO firms. The standard errors are corrected for heteroskedasticity using the Huber-White correction and are clustered by firm. Estimates marked with an asterisk indicate statistical significance based on two-tail tests, and the $t$-statistics are reported under each coefficient.

Column 1 of Panel A reports the results from estimating CEO compensation on firm and peer performance without the interaction with other firm characteristics. CEO compensation is positively associated with firm performance with a coefficient of $0.31(\mathrm{p}<0.01)$. This coefficient is close to the values reported in Hall and Liebman (1998). CEO compensation is negatively associated with peer performance (coefficient of -0.08 , with a $t$-statistic of -2.30 ), providing evidence of RPE use. The control variables included in the regression show that CEOs at larger firms and with longer tenures are paid more. I also find that firms with more growth options pay their CEOs more, possibly to retain more talented individuals, except when R\&D is used as a proxy for GO, in which case the coefficient is negative but not statistically significant. The governance variables are not statistically significant, reflecting the inclusion of the CEO-fixed effects. $^{12}$

The regressions in columns (2) through (7) use mean-centered values of the independent variables when interacted with firm or peer performance. The use of mean-centered values alleviates multicollinearity concerns arising from the introduction of interaction terms among the continuous variables and facilitates the interpretation of the results (Aiken and West 1991; Chen

\footnotetext{
${ }^{12}$ When CEO-fixed effects are not included in the regression, the untabulated results show that CEOs who are board chairs, have lower stock ownership, and have no interlocking positions are paid higher total compensation.
} 
et al. 2012). The main results of the paper are not affected by this procedure. The pay-forperformance sensitivity is equal to the coefficient $\eta_{1}$ in Equations (1) and (2) and the pay-forpeer-performance sensitivity is equal to $\eta_{3}$ in the same equations.

In columns 2 and 3 of Panel A, I present the results when the definition of the GO proxy is the ratio of the market-to-book value of assets. In column 2, the pay-for-performance is estimated at 0.31 ( $t$-statistic of 9.57) and the pay-for-peer-performance is estimated at $-0.09(t-$ statistic of -2.77). The coefficient on firm performance interacted with GO is not statistically significant. Although this result appears inconsistent with larger pay-for-performance sensitivity for GO firms, other studies find the same result (e.g., Bizjak et al. 1993; Yermack 1995; Garvey and Milbourn 2003). In contrast, the coefficient on firm performance interacted with GO is negative and statistically significant in columns 4,5 , and 6 when growth options are measured by the firm's level of R\&D or the factor. This evidence is again consistent with Bizjak et al. (1993) and Yermack (1995).

The coefficient on peer performance interacted with GO is $0.08(\mathrm{p}<0.01)$. This provides evidence that GO firms put lower weight on peer performance, which supports the argument that the costs of implementing RPE outweigh the benefits for high GO firms.

Column 3 of Panel A presents the results when firm and peer performances are allowed to vary with other firm characteristics in addition to GO. The estimated value for the pay-forperformance is 0.35 ( $t$-statistic of 10.83). The estimated value for the pay-for-peer-performance sensitivity is -0.13 ( $t$-statistic of -3.78 ), which provides evidence that the common external shocks are removed from CEO compensation contracts through RPE. The coefficient associated with the interaction between firm performance and idiosyncratic variance is -0.20 ( $t$-statistic of 2.24). The coefficient associated with firm performance interacted with CEO tenure is $0.09(t-$ 
statistic of 3.24). The coefficient on firm performance interacted with GO remains statistically insignificant.

Considering the various interactions with peer performance in the regression reported in column 3 of Panel A in Table 5, the coefficients on peer performance interacted with GO and Correlation are 0.08 ( $t$-statistic of 2.80) and -0.17 ( $t$-statistic of -2.47$)$, respectively, with the predicted signs. The sign of the coefficient on Correlation interacted with the peer performance is consistent with the prediction in Holmstrom and Milgrom (1987) that RPE use will be higher for firms with higher correlation. This finding contrasts with the evidence in Aggarwal and Samwick (1999a), who do not find that a firm's level of RPE varies with the correlation between firm and peer performance. The coefficient on peer performance interacted with a firm's level of growth options is still statistically significant after controlling for the correlation between firm and peer performance. In Section IV, I find that high GO firms exhibit a lower correlation between firm and peer performance. Thus the variable Correlation also captures the extent to which the peer performance is a noisier benchmark for common risk to high GO firms. In addition, the model in Appendix A shows that the coefficient associated with peer performance depends on both the Correlation and the noise with which the covariance between firm and peer performance is estimated. If this noise is a function of the GO level, then GO has an effect over and above the correlation. The coefficients on the interactions of peer performance with idiosyncratic variance, CEO tenure, and the Herfindahl index are not statistically significant.

Column (3) of Panel B of Table 5 reports the tests on the level of RPE use for the average firm and also for high and low GO firms defined as the firms in the top and bottom quartile of growth options, respectively. The RPE value used in the tests is calculated using the estimated coefficients obtained from Column (3) of Panel A. Because of the demeaning procedure, the 
value of RPE for the average firm is simply $\eta_{3} / \eta_{1}$. The results show that the RPE value for the average firm is -0.37 ( $p$-value of 0.00). In Holmstrom and Milgrom (1987), the optimum amount of RPE should equal the negative of the mean correlation value of -0.75 (see Table 3), which means that by using RPE, the average firm can remove almost 50 percent (i.e., $-0.37 /-0.75$ ) of the common shocks that the CEO is exposed to through incentive pay. More importantly, the estimated RPE for high GO firms $(-0.31$, with $\mathrm{p}<0.01)$ is almost half the level of RPE for low GO firms $(-0.53$, with $\mathrm{p}<0.01)$.

The results in columns 4 and 5, when a firm's level of growth options is represented by R\&D expenses scaled by assets, and in columns 6 and 7, when a firm's level of growth options is represented by the factor, are similar to those discussed above.

\section{Evidence of RPE Across Industries}

Panel C of Table 5 reports on the implied RPE use in CEO compensation contracts across industries. To obtain the statistics in this panel, I calculate the firm-specific RPE by computing $\alpha_{1}=\eta_{1}+\eta_{2} \mathrm{GO}+\eta_{5}$ Id.Var $+\eta_{6}$ CEOTenure $+\eta_{7}$ HerfindahlIndex, and $\alpha_{2}=\eta_{3}+\eta_{4} \mathrm{GO}+\eta_{8}$ Correlation $+\eta_{9}$ Id.Var $+\eta_{10}$ CEOTenure $+\eta_{11}$ HerfindahlIndex, using the demeaned value of each variable for firm $i$ at time $t$, and by taking the ratio of the coefficients, i.e., $\mathrm{RPE}_{\mathrm{it}}=\alpha_{2 \mathrm{it}} / \alpha_{1 \mathrm{it}}$. This RPE measure uses the estimated coefficients from Column (3) of Panel A. Specifically, the RPE measure for firm $i$ at time $t$ is calculated as $\left[-0.13+0.08 \times \mathrm{GO}_{\mathrm{it}}-0.17 \times \mathrm{Corr}_{\mathrm{it}}+0.18 \times \mathrm{IdVar}_{\mathrm{it}}-\right.$ $0.03 \times$ Tenure $_{i t}-0.01 \times$ HerfindahlIndex $\left._{i t}\right] /\left[0.35-0.00 \times \mathrm{GO}_{\text {it }}-0.20 \times \mathrm{IdVar}_{i t}+0.09 \times\right.$ CEOTenure $_{i t}-$ $0.05 \times$ HerfindahlIndex $\left._{i t}\right]$. This estimated firm-specific RPE measure is aggregated at the twodigit GICS industry level to verify the extent to which growth options are a major driver of RPE versus other firm characteristics. The observations in the table are ranked according to their estimated RPE values and show that the sectors appearing to rely the most on RPE are utilities, 
financials (banks, diversified financial services, insurance and real estate), and energy (energy equipment and services, oil and gas). The industry that uses the lowest level of RPE is health care (equipment, pharmaceuticals, and biotechnology). This ranking broadly agrees with the paper's main results because the industries that rely less (more) on RPE are characterized by high (low) levels of GO, consistent with the results in Panel B of Table 3. It is also consistent with the survey evidence provided by Murphy (1999) on the explicit use of RPE in bonuses, where RPE use is more prevalent in financial and utilities firms and less so in industrial firms. In conclusion, GO seem to be an important driver in explaining RPE use across industries. ${ }^{13}$

\section{Alternative Peer Group Classifications}

This subsection reports the results using different peer-group classifications. First, I report the results using industry-GO peers. If high GO firms face different systematic risk, then using other high GO firms as the relevant peer group should be the most effective method to control for that risk. For example, an interest rate shock can change the value of a high GO firm differently than the value of a low GO firm because high GO firms have a higher proportion of their value in future growth opportunities, which can become unprofitable after interest rates go up. To address this concern, I perform the tests above using peer groups based on the firms in the same six-digit GICS and GO (defined by the market-to-book value of assets) quartile as that of the firm. The evidence in Table 6 shows that the results are qualitatively similar to those in Table 5.

(Place Table 6 Here)

The SIC codes were developed in the 1930s by an Interdepartmental Committee on

\footnotetext{
${ }^{13}$ As a robustness check, I also estimate RPE usage for each industry by estimating the regression model in column 1 of Table 5 at the industry level, defined at the two-digit GICS code. I estimate the model in Column 1 without the year dummies because the number of observations drops considerably when the estimation is done at an industry level, which leads to a lack of power to estimate the coefficients. The RPE use estimated directly at the industry level (untabulated) is broadly consistent with the use reported in Panel C of Table 5.
} 
Industrial Statistics, established by the Central Statistical Board of the United States, and were last updated in 1987. The NAICS, which replaced the SIC system, was created jointly by the U.S., Canada, and Mexico in 1999 to respond to the rapidly changing economy and to ensure comparability of business activities across North America. ${ }^{14}$ Both the SIC and the NAICS classifications group firms according to their "similarity in the process used to produce goods or services" (NAICS 1998 Manual from the Office of Management and Budget), but the GICS groups firms according to their revenue source. Table 7 replicates the regression results and the hypotheses tests from Table 5 using peer groups defined at the three-digit NAICS code and size quartiles. The number of observations in Table 7 increases to about 22,000 because the NAICS codes are available since 1992, and thus I can include firm-year observations for 1992 to 1995. The results are virtually the same. In untabulated analysis, I use peer performance based on the two-digit SIC codes and size quartiles and also obtain similar results.

The results presented in the paper are also robust (in untabulated analysis) to defining peers based on firms in the same industry only, defined by the six-digit GICS code, instead of the same industry and size quartile. Overall, these results provide evidence that the inference regarding RPE use for GO firms is robust to alternative peer groupings.

(Place Table 7 Here)

\section{Further Analysis}

The previous subsection established that firms with high GO use less RPE even after controlling for the correlation between firm and peer performance. In this subsection, I use data

\footnotetext{
${ }^{14}$ NAICS includes some new classifications of industries to reflect technological and business changes. Examples are fiber-optic cable manufacturing, satellite communications, and the reproduction of computer software as well as bed and breakfast inns, environmental consulting, warehouse clubs, pet supply stores, credit card issuing, diet and weight reduction centers.
} 
on firms' disclosure of performance peers to check whether high GO firms disclose less use of RPE and whether those that do disclose using RPE rely on fewer actual peers.

The SEC amended the proxy disclosure rules in 2006 to require firms to disclose how they use performance targets in setting CEO pay, including the disclosure of RPE peers. I collect data from proxy statements submitted after the new rule took effect on Dec. 15, 2006, for a sample of 750 firms for the fiscal years of 2006 to $2008 .{ }^{15}$ Panel A of Table 8 shows that 28.5 percent of the sampled firms explicitly disclose using RPE for CEO compensation purposes. Consistent with the above results, and with the idea that the net benefits of RPE for high GO firms are lower than for low GO firms, there is a larger proportion of low GO firms that state using RPE (34.8 percent) than of high GO firms (21.4 percent), and the difference is statistically significant (untabulated $\mathrm{p}<0.01$ ). Panel $\mathrm{B}$ shows that, for the firms disclosing RPE peers, the number of actual peers is higher for the firms with low GO than for the firms with high GO. The mean (median) number of actual peers for the firms in the bottom tercile of GO is 16.75 (16), larger than the 16.29 (13) actual peers for the top tercile, although only the difference in medians is statistically significant (untabulated $\mathrm{p}<0.05$ ). While these differences are small, they are consistent with the number of available peers being smaller for high GO firms as reported in Table 3. Furthermore, these differences are likely to represent a lower bound as they rely on an analysis of the number of peers reported by the firms that explicitly disclose that they use RPE. If firms disclose that they use RPE when the benefits of using RPE are higher and if the benefits are higher when there are more peers, then this implies that the difference in the number of disclosed peers among high and low GO firms should be small.

\footnotetext{
${ }^{15}$ I search the compensation, discussion and analysis section of firms' proxy statements (DEF 14A) for any mention that the CEO compensation is tied to the firm's performance measured against the performance of its peers. For an example of a firm that I coded as using RPE, the 2007 proxy statement for Ashland Inc. reports that, "Ashland must achieve median performance relative to the Performance Peer Group in order for eligible executives to earn a target award under the Long-Term Incentive Plan.”
} 
(Place Table 8 Here)

To further corroborate the analysis above, I test whether the estimated firm-specific RPE measure is larger for the firms that disclose using RPE from 2006 through 2008 (the period for which there is disclosure data). Panel $\mathrm{C}$ of Table 8 shows the firm-specific RPE measure, calculated using the coefficients obtained from column 3 of Table 5, for the years of 2006 to 2008. The table reports mean and median RPE usage for the full sample of firms, for the subsample that discloses using RPE, and for the subsample that does not disclose using RPE. The first row presents the results for all firms, and the second and third rows present the results for the high and low GO firms, respectively. I define high (low) GO firms as firms in the top (bottom) tercile of the distribution according to their MVA/BVA in 2006. The results show that the estimated RPE use is higher for the disclosing firms (mean of -0.44) than it is for the nondisclosing firms (mean of -0.30 ), and the difference is statistically significant $(\mathrm{p}<0.01)$. The high GO firms drive this difference, because the estimated RPE use for high GO firms that disclose using RPE (mean of -0.17$)$ is statistically significantly $(\mathrm{p}<0.01)$ higher than the estimated RPE use for similar firms that do not disclose using RPE (mean value of 0.02 ), whereas for low GO firms, the difference is very small and statistically insignificant. This evidence suggests that high GO firms that rely on RPE do so because they have greater net benefits from doing so, perhaps reflecting greater availability of peers. Furthermore, the amount of RPE usage for high GO firms that disclose using RPE is lower (mean of -0.17) than it is for RPE-disclosing low GO firms (mean value of -0.60 ), and the difference is statistically significant (untabulated $\mathrm{p}<0.01$ ), corroborating the findings from Table 5. Finally, similar evidence arises when looking at the frequency with which firms disclose using RPE. For the firms disclosing RPE peers, the proportion of high GO firms (26 percent) is lower than the proportion of low GO firms (39 
percent). For the firms not disclosing RPE peers, the percentage of high GO firms (37 percent) is larger than the percentage of low GO firms (29 percent). This evidence corroborates the findings in the paper that high GO firms rely less on RPE.

Consistent with results in Black et al. (2011) that firms use RPE despite not disclosing it in proxy statements, the firm-specific use of RPE in low GO disclosing firms (mean of -0.60) is close to RPE use in low GO non-disclosing firms (mean of -0.58). One explanation for this finding is that many firms choose not to write explicit compensation contracts. Gillan et al. (2009) show that less than half of the firms in the S\&P 500 in 2000 had a comprehensive written (or explicit) employment contract with their CEOs. Finding that GO firms tend to disclose less explicit use of RPE can either reflect that these firms rely less on RPE or that they have less explicit contracts. In the latter case, it is relevant to rely on implicit tests to detect RPE use. Despite this limitation, the analysis of explicit contracts provides supporting evidence for the findings in this paper.

\section{ROBUSTNESS TESTS}

Garvey and Milbourn (2003) argue that firms are less likely to offer compensation contracts exhibiting RPE when the CEOs can hedge market risk. Following Garvey and Milbourn (2003), I use the CEO's firm-specific equity wealth or the CEO's age to capture the CEO's self-hedging ability. The definition of the CEO's equity wealth is the total dollar value of shares and options in the firm owned by the CEO. ${ }^{16}$ The main results are robust to controlling

\footnotetext{
${ }^{16}$ The ideal variable for this exercise, i.e., the CEO's overall wealth, is unobservable. The measure of CEO equity wealth used poses some challenges. First, a CEO that has significant wealth tied up in the firm is likely more risk averse. Rather than being a proxy for hedging activity, CEO wealth can be a proxy for risk-aversion. Second, CEO firm-specific wealth is highly correlated with tenure (more years of equity grants) and with growth options because high GO firms tend to provide greater equity pay.
} 
for both measures of the CEO's hedging ability. ${ }^{17}$ However, I find that CEOs with more equity wealth use less RPE, which is consistent with the argument in Garvey and Milbourn (2003) that these CEOs can arrange insurance contracts on their own.

Another explanation for the above results is that high GO firms use less RPE because they have greater need to attract and retain their CEOs. Himmelberg and Hubbard (2000) and Oyer (2004) argue that rewarding CEOs for positive industry performance can be part of an optimal contract if CEOs' reservation wages are positively related to overall industry performance. This is the case for CEOs who have specific skills or talents and are therefore scarce, where a positive shock to the industry raises the industry's equilibrium wage and hence their reservation wage. If firms with high GO require CEOs with specific and hard-to-find skills, then compensation should be tied to industry performance to retain these executives. In this case, firms with higher GO appear to use less RPE. Following the suggestion of Himmelberg and Hubbard (2000), I use firm size has a proxy for CEO outside job opportunities. The main results remain the same. The results are also robust to using lagged industry-adjusted return on assets as a proxy for the CEO's outside opportunities, as suggested by Rajgopal et al. (2006).

Baker and Hall (2004) also show that the pay-for-performance sensitivity using stock returns as a measure of firm performance varies positively with firm size because these firms tend to use higher levels of incentive pay (Core and Guay 1999, 2002). I control for this fact by interacting firm performance with firm size. If the pay-for-performance sensitivity is higher for larger firms, then the expectation is that the pay-for-peer-performance sensitivity is also larger for these firms because of a greater need to insulate CEOs from the extra risk imposed on them. Again, the paper's main results remain unchanged when the interaction between firm size and

\footnotetext{
${ }^{17}$ The results in this section are untabulated.
} 
peer performance is included.

Further, Garvey and Milbourn (2006) find that CEOs use RPE when it is in their interest to do so, that is, only when the overall market displays negative returns. Following Garvey and Milbourn (2006), I include an interaction term between the weight on peer performance and a dummy that takes the value of one if peer performance is negative and zero otherwise. I find that the results reported in Table 5 remain qualitatively the same. I also test whether the results are affected by the impact of the market corrections of 2001 and 2008. I perform two types of tests. First, I exclude the years of 2001 and 2008 from the main analysis. Second, I use the full sample to perform the analysis, but I allow the coefficients on the variables of interest to differ for the market correction years. The results from these tests imply that RPE is used more during the market correction years, but this evidence is not always statistically significant. The GO results regarding RPE use are not affected by the market correction years.

\section{CONCLUSION}

The use of RPE in compensation contracts can be more beneficial for CEOs of growthoption firms who are exposed to greater systematic risk than for CEOs of firms with more assets in place. RPE can insulate CEOs of GO firms from common exogenous shocks to firm performance and thus reduce the amount of risk that they face. However, the use of RPE for growth-option firms can be impaired by the high costs associated with the implementation of RPE, such as the inability of GO firms to find a peer group that captures common risk exposure. Given these conflicting effects, this study analyzes the extent to which GO firms use RPE.

I find that the level of RPE in CEO compensation contracts varies negatively with a firm's level of growth options. The results are robust to several alternative explanations. 
Understanding how GO firms rely on RPE is relevant to scholars because it affects RPE tests, but also to practitioners because it is more difficult to identify the peer group to evaluate CEO performance in high GO firms.

The interpretation of the results is subject to an important caveat. The evidence provided in this paper supports a joint hypothesis that high GO firms use less RPE and that the appropriate peer group has been identified. However, suppose that there is indeed an ideal peer group for every firm — including one for high GO firms — but that the empirical proxy used to identify the peer group is particularly poor for high GO firms. Then the results in this paper also support the alternative hypothesis that the peer-group definition used is worse for high GO firms. In an effort to distinguish between these alternative interpretations, I repeat the analysis under several alternative peer-group definitions, including industry-size, industry-GO, and industry, and obtain similar qualitative results. Moreover, the explicit evidence on RPE also corroborates the results in the paper, but is inconsistent with the alternative explanation. Despite these attempts, I cannot fully rule out this concern.

CEOs of high GO firms tend to bear more risk than CEOs of low GO firms because GO firms have more idiosyncratic variance and use less RPE. How the board of directors deals with the increased risk faced by CEOs of high GO firms is an interesting topic for future research. 


\section{APPENDIX A}

This appendix presents a simple model based on Holmstrom and Milgrom (1987) of how the noise in the estimation of the covariance between firm and peer performance affects relative performance evaluation.

Consider a linear compensation contract to the agent of the form

$$
w=\alpha_{0}+\alpha_{1} x+\alpha_{2} y
$$

where $w$ represents pay, and $x$ and y represent firm and peer performance, respectively. Both variables are assumed to be normally distributed with $x \sim N\left(\mu_{x}, \sigma_{x}^{2}\right)$ and $y \sim N\left(\mu_{y}, \sigma_{y}^{2}\right)$. The firm's principal and agent both observe a covariance between $x$ and $y$ of $\hat{\sigma}_{x y}$ and try to infer the value of the true covariance from this noisy estimate as described below. The compensation parameters $\alpha_{0}, \alpha_{1}$, and $\alpha_{2}$, are determined optimally.

Assume that the agent has exponential utility over $w$ with risk aversion $r$. The agent incurs a utility cost of $k \mu_{x}^{2} / 2$ to generate $\mu_{x}$. Then, the agent's certainty equivalent conditional on the observed covariance is

$$
C E=E(w)-\frac{r}{2} V(w)-k \mu_{x}^{2} / 2
$$

where $E(w)=\alpha_{0}+\alpha_{1} \mu_{x}+\alpha_{2} \mu_{y}$, and $V(w)$ is the variance of pay.

The agent chooses $\mu_{x}$ to maximize the certainty equivalent. The solution to this problem yields $\mu_{x}=\alpha_{1} / k$. Given this choice, the principal chooses the compensation parameters to maximize profits, $E[x-w]$, subject to a participation constraint that sets a lower bound to the agent's certainty equivalent of $C E \geq \overline{C E}$.

The following assumption introduces an additional feature to the standard model. It is assumed that the covariance between $x$ and $y$ is observed with noise:

$$
\hat{\sigma}_{x y}=\tilde{\sigma}_{x y}+\varepsilon
$$


where $\hat{\sigma}_{x y}$ is the observed covariance; $\tilde{\sigma}_{x y}$ is the true, unobserved covariance; and $\varepsilon$ is an i.i.d. error term with $\varepsilon \sim N\left(0, \sigma_{\varepsilon}^{2}\right)$. This modeling assumption rests on the fact that the sample covariance is an estimate of the true covariance between firm and peer performance. If the true covariance is distributed according to $\tilde{\sigma}_{x y} \sim N\left(0, \sigma_{c}^{2}\right)$, then the best estimate of the true covariance given the observed level is

$$
E\left[\tilde{\sigma}_{x y} \mid \hat{\sigma}_{x y}\right]=\frac{\sigma_{c}^{2}}{\sigma_{c}^{2}+\sigma_{\varepsilon}^{2}} \hat{\sigma}_{x y} .
$$

Intuitively, when the signal is very noisy $\left(\sigma_{\varepsilon}^{2}=\infty\right)$, then the best estimate of the covariance is the unconditional covariance of zero. When the signal is very precise $\left(\sigma_{\varepsilon}^{2}=0\right)$, then the best estimate of the covariance is the observed value: $\hat{\sigma}_{x y}$. The solution for the variance of pay given the observed covariance is

$$
V(w)=\alpha_{1}^{2} \sigma_{x}^{2}+\alpha_{2}^{2} \sigma_{y}^{2}+2 \alpha_{1} \alpha_{2} E\left[\tilde{\sigma}_{x y} \mid \hat{\sigma}_{x y}\right] .
$$

To solve the problem faced by the principal, the fixed component of pay, $\alpha_{0}$, is chosen so that the agent's $C E$ equals the participation level. Substituting this solution into the principal's objective function generates the problem:

$$
\max _{\alpha_{1}, \alpha_{2}}\left\{\frac{\alpha_{1}}{k}-\overline{C E}-\frac{r}{2} V(w)-\alpha_{1}^{2} / 2 k\right\} .
$$

The solution to this problem yields

$$
\alpha_{1}=1 /\left[1+r k\left(1-\rho^{2}\right) \sigma_{x}^{2}\right]
$$

and, RPE is given by,

$$
\alpha_{2} / \alpha_{1}=-\left(\sigma_{c}^{2} /\left(\sigma_{c}^{2}+\sigma_{\varepsilon}^{2}\right)\right) /\left(\hat{\sigma}_{x y} / \sigma_{y}^{2}\right) .
$$

In this solution, $\rho$ is the correlation between firm and peer performance conditional on the observed covariance. The solution for RPE coincides with the solution in Holmstrom and 
Milgrom (1987) with one exception. When the covariance is observed without noise $\left(\sigma_{\varepsilon}^{2}=0\right)$, I recover the usual expression for RPE:

$$
\frac{\alpha_{2}}{\alpha_{1}}=-\frac{\hat{\sigma}_{x y}}{\sigma_{y}^{2}}
$$

The novelty of this simple model is to show that the estimation noise, $\sigma_{\varepsilon}^{2}$, can reduce the use of RPE with the downward adjustment of $\frac{\sigma_{c}^{2}}{\sigma_{c}^{2}+\sigma_{\varepsilon}^{2}}$. As hypothesized in the main text, if high GO firms have higher estimation noise for the covariance between the firm and the peer performance, then it is optimal to use less RPE. 


\section{REFERENCES}

Aggarwal, R., and A. Samwick. 1999a. The Other Side of the Trade-off: The Impact of Risk on Executive Compensation. Journal of Political Economy 107: 65-105.

Aggarwal, R., and A. Samwick. 1999b. Executive Compensation, Strategic Competition, and Relative Performance Evaluation: Theory and Evidence. Journal of Finance 54: 1999-2043.

Aiken, S., and S. West. 1991. Multiple Regression: Testing and Interpreting Interactions. Newbury Park, CA: Sage.

Albuquerque, A. 2009. Peer Firms in Relative Performance Evaluation. Journal of Accounting and Economics 48: 69-89.

Albuquerque, A., G. DeFranco, and R. Verdi. 2012. Peer choice in CEO compensation. Journal of Financial Economics. (forthcoming).

Albuquerque, R., A. Durnev, and Y. Koskinen. 2012. Corporate Social Responsibility and Asset Pricing in Industry Equilibrium. Working paper, Boston University, and University of Iowa.

Baber, W., S. Janakiraman, and S. Kang. 1996. Investment Opportunities and the Structure of Executive Compensation. Journal of Accounting and Economics 21: 297-318.

Baker, G., and B. Hall. 2004. CEO incentives and firm size. Journal of Labor Economics 22: 767-798.

Bertrand, M., and S. Mullainathan. 2001. Are CEOs rewarded for luck? The ones without principals are. The Quarterly Journal of Economics 116: 901-32.

Bhojraj, S., C. Lee, and D. Oler. 2003. What's my line? A comparison of industry classification schemes for capital market research. Journal of Accounting Research 41(5): 745-774.

Bizjak, J., J. Brickley, and J. Coles. 1993. Stock-based incentive compensation and investment behavior. Journal of Accounting and Economics 16: 349-372.

Bizjak, J., M. Lemmon, and T. Nguyen. 2011. Are all CEOs above average? An empirical analysis of compensation peer groups and pay design. Journal of Financial Economics 100, 538-555.

Black, D., S. Dikolli, and C. Hoffmann. 2011. Peer Group Composition, Peer Performance Aggregation, and Detecting Relative Performance Evaluation. Working paper, Duke University, and Munich School of Management.

Boni, L., and K. Womack. 2006. Analysts, industries, and price momentum. Journal of Financial and Quantitative Analysis 41: 85-109. 
Cadman, B., and M. Carter. 2011. Compensation peer groups and their relation with CEO compensation. Working paper, University of Utah, and Boston College.

Campbell, J., and T. Vuolteenaho. 2004. Bad beta, good beta. The American Economic Review 94: 1249-1275.

Cao, C., T. Simin, and J. Zhao. 2008. Can Growth Options Explain the Trend in Idiosyncratic Risk? Review of Financial Studies, 2008: 2599-2633.

Carter, M., C. Ittner, and S. Zechman. 2009. Explicit relative performance evaluation in performance-vested equity grants. Review of Accounting Studies 14: 269-306.

Clinch, G. 1991. Employee compensation and firm's research and development activity. Journal of Accounting Research 29: 59-78.

Chen, C., H. Lu, and T. Sougiannis. 2012. The agency problem, corporate governance, and the asymmetrical behavior of selling, general, and administrative costs. Contemporary Accounting Research 29: 252-282.

Cohen, R., Polk, C., and Vuolteenaho, T. 2010. The Price is (Almost) Right. Journal of Finance. (forthcoming).

Coles, J., and Z. Li. 2010. Managerial attributes incentives and performance. Working paper, Arizona State University, and University of Western Ontario.

Core, J., and W. Guay. 1999. The use of equity grants to manage optimal incentive levels. Journal of Accounting and Economics 28: 151-184.

Core, J., and W. Guay. 2002. The other side of the trade-off: The impact of risk on executive compensation - a revised comment. Working Paper, Wharton School.

Core, J., R. Holthausen, and D. Larcker. 1999. Corporate governance, Chief Executive Officer compensation, and firm performance. Journal of Financial Economics 51: 371-406.

Dechow, P., and R. Sloan. 1991. Executive incentives and the horizon problem: An empirical investigation. Journal of Accounting and Economics 14: 51-89.

Demers, E., and B. Lev. 2001. A rude awakening: Internet shakeout in 2000. Review of Accounting Studies 6: 331-359.

Diamond, D., and R. Verrecchia. 1982. Optimal Managerial Contracts and Equilibrium Prices. The Journal of Finance 37: 275-287.

Dye, R. 1992. Relative performance evaluation and project selection. Journal of Accounting Research 30: 27-52.

Fama, E., and K. French. 1997. Industry cost of equity. Journal of Financial Economics 43: 153193. 
Fama, E., and K. French. 2004. New lists: Fundamentals and survival rates. Journal of Financial Economics 73: 229-269.

Faulkender, M., and J. Yang. 2010. Inside the black box: The role and composition of compensation peer groups. Journal of Financial Economics 96, 257-270.

Garvey, G., and T. Milbourn. 2003. Incentive compensation when executives can hedge the market: Evidence of relative performance evaluation in the cross section. The Journal of Finance 58: $1557-1581$.

Garvey, G., and T. Milbourn. 2006. Asymmetric benchmarking in compensation: Executives are rewarded for good luck but not penalized for bad. Journal of Financial Economics 82: 197226.

Gaver, J., and K. Gaver. 1993. Additional evidence on the association between the investment opportunity set and corporate financing, dividend, and compensation policies. Journal of Accounting and Economics 16: 125-160.

Gerakos, J., C. Ittner, and D. Larcker. 2007. The structure of performance-vested stock option grants. In Essays on Accounting Theory in Honor of Joel S. Demski, edited by R. Antle, P. Liang, F. Gjesdahl. Springer.

Gibbons, R., and K. Murphy. 1990. Relative performance evaluation for chief executive officers. Industrial and Labor Relations Review 43: 30-51.

Gibbons, R., and K. Murphy. 1992. Optimal incentives in the presence of career concerns: Theory and evidence. Journal of Political Economy 100: 468-505.

Gillian, S., J. Hartzell, and R Parrino. 2009. Explicit versus implicit contracts: Evidence from CEO employment agreements. The Journal of Finance 64: 1629-1655.

Gomes, J., L. Kogan, and L. Zhang. 2003. Equilibrium cross-section of returns. Journal of Political Economy 111: 693-732.

Gong, G, L. Li, and J. Shin. 2011. Relative performance evaluation and related peer groups in executive compensation contracts. The Accounting Review 86 (3): 1007-1043.

Graham, J., S. Li, and J. Qui. 2011. Managerial attributes and executive reputation. Review of Financial Studies, 24, 1944-1979.

Grinblatt, M., and S. Titman. 2001. Financial Markets and Corporate Strategy (2nd Ed.) New York, NY: McGraw-Hill.

Hall, B., and J. Liebman. 1998. Are CEOs really paid like bureaucrats? Quarterly Journal of Economics 113: 653-691.

Himmelberg, C., R. Hubbard, and D. Palia. 1999. Understanding the determinants of managerial ownership and the link between ownership and performances. Journal of Financial 
Economics 53: 353-384.

Himmelberg, C., and R. Hubbard. 2000. Incentive pay and the market for CEOs: An analysis of pay-for-performance sensitivity. Working Paper, Columbia University.

Holmstrom, B. 1979. Moral hazard and observability. Bell Journal of Economics 10: 74-91.

Holmstrom, B. 1982. Moral hazard in teams. Bell Journal of Economics 13: 324-340.

Holmstrom, B., and P. Milgrom. 1987. Aggregation and linearity in the provision of intertemporal incentives. Econometrica 55: 303-328.

Janakiraman, S., R. Lambert, and D. Larcker. 1992. An empirical investigation of the relative performance evaluation hypothesis. Journal of Accounting Research 30: 53-69.

Kogan, L., and D. Papanikolaou. 2012. A theory of firm characteristics and stock returns: The role of investment-specific shocks. Working paper, NBER.

Kole, S. 1997. The complexity of compensation contracts. Journal of Financial Economics 43: $79-104$.

Milgrom, P. 1988. Employment contracts, influence activities and organization design. Journal of Political Economy 96: 42-60.

Murphy, K. 1999. Executive compensation. In Handbook of Labor Economics, edited by O. Ashenfelter, and D. Card. Elsevier.

Murphy, K. 2001. Performance standards in incentive contracts. Journal of Accounting and Economics 30: 245-278.

Myers, S. 1977. Determinants of corporate borrowing. Journal of Financial Economics 5: 147175.

Office of Management and Budget. 1998. North American Industry Classification System. Bernan Press: Lanham, MD.

Oyer, P. 2004. Why do firms use incentives that have no incentive effects? The Journal of Finance 59: 1619-1649.

Pastor, L., and P. Veronesi. 2003. Stock valuation and learning about profitability. The Journal of Finance 58: 1749-1789.

Petkova, R., and L. Zhang. 2005. Is value riskier than growth? Journal of Financial Economics 78: $187-202$.

Rajgopal, S., T. Shevlin, and V. Zamora. 2006. CEO's outside employment opportunities and the lack of relative performance evaluation in compensation contracts. Journal of Finance 61: $1813-1844$. 
Rosen, S. 1982. Authority, control, and the distribution of earnings. The Bell Journal of Economics 13: 311-323.

Schwert, W. 2002. Stock volatility in the new millennium: How wacky is Nasdaq? Journal of Monetary Economics 49: 3-26.

Smith, C. Jr., and R. Watts. 1992. The investment opportunity set and corporate financing, dividend, and compensation policies. Journal of Financial Economics 32: 263-292.

Tirole, J. 1988. The Theory of Industrial Organization. Cambridge, MA: MIT Press.

Yermack, D. 1995. Do corporations award CEO stock options effectively? Journal of Financial Economics 39: 237-269.

Yim, A. 2001. Renegotiation and relative performance evaluation: Why an informative signal may be useless. Review of Accounting Studies 6: 77-108. 
TABLE 1

Summary of Sample Selection Process

The sample covers 1995 to 2008

\begin{tabular}{lr}
\hline \hline & CEO-years \\
\hline Initial sample with CEO compensation data from ExecuComp & 22,774 \\
$\begin{array}{l}\text { Observations with missing Compustat data, Global industry Classification } \\
\text { Code, and Governance measures }\end{array}$ & $(4,420)$ \\
Observations with missing Portfolio Return, Beta, and Idiosyncratic Variance & $(1,926)$ \\
Drop top and bottom 1\% of observations for GO proxies and stock returns & $(871)$ \\
Final sample & 15,557 \\
\hline \hline
\end{tabular}


TABLE 2

Definition of Variables Used in the Empirical Tests

\title{
Variable
}

\author{
Variable Definitions
}

\begin{abstract}
Total Flow
Defined as the natural logarithm of total compensation, where total compensation is data item

Compensation

TDC1 from ExecuComp. TDC1 is comprised of salary, bonus, other annual, total value of restricted stock granted, total value of stock options granted (using the Black-Scholes formula), long-term incentive payouts, and all other, for fiscal years ending before Dec. 15, 2006. For fiscal years ending after Dec. 15, 2006, TDC1 is defined as the sum of the salary, bonus, nonequity incentive plan compensation, grant-date fair value of stock awards, grant-date fair value of option awards, deferred compensation, and other compensation. The total annual flow compensation is measured in real terms (base Jan/1992 for CPI) and deflated using the value of the CPI index of the corresponding fiscal month.
\end{abstract}

Cash Cash compensation comprises the salary, bonus, and long-term incentive payouts before Dec. Compensation 15, 2006; and the salary, bonus, and non-equity incentive plan compensation after Dec. 15, 2006.

Equity Equity compensation comprises the total value of the restricted stock granted and the total value Compensation of the stock options granted (using the Black-Scholes formula) before Dec. 15, 2006; and the grant-date fair value of the stock awards and the grant-date fair value of the option awards after Dec. 15, 2006.

Firm Firm performance is measured using stock returns as the natural logarithm of the annual real Performance stock return assuming that the dividends are reinvested (i.e., $\ln ((1+$ retann $/ 100) /(1+$ CPIANN)), where "retann" is the annual (compounded) stock return obtained from the CRSP monthly tapes, and CPIANN is the annual rate of CPI inflation from CRSP-Indexes-U.S. Treasury and Inflation). In the sensitivity analysis section, I use both accounting and market measures of performance. Accounting returns are defined as the natural logarithm of one plus the annual income before extraordinary items divided by the average of total assets calculated using beginning and ending year total assets.

Peer $\quad$ First, portfolios are formed annually based on industry codes (defined at the six-digit GICS Performance code) using all the firms in the merged CRSP-Compustat dataset. Use of all of the firms ensures that relevant peers are included even if they are not in ExecuComp. Second, firms in an industry portfolio are sorted by market value at the end of the previous fiscal year-end to determine the size quartiles in each industry portfolio, and firms are allocated to each industry-size grouping. Third, each firm is matched with an industry-size peer group, which excludes the own firm, and a simple average portfolio return using the firm-specific peer group is computed. I require a minimum of two peer firms per industry-size group to calculate its return.

Firm Size The natural logarithm of sales in constant 1992 dollars. 


\section{TABLE 2 (Continued) Definition of Variables Used in the Empirical Tests}

Variable

Growth Options

Correlation

Idiosyncratic Variance

CEO Tenure

CEO Tenure Dummy

Corporate Governance

Industry Dummies

CEO Wealth

Herfindahl Index

\section{Variable Definitions}

Three different proxies are used. The first proxy is the ratio of the market value of the firm to the book value of assets (MVA/BVA). The market value of the firm is the book value of total assets (data item AT from Compustat), minus the book value of equity (data item CEQ plus deferred taxes [or data item TXDITC] from Compustat), plus the market value of equity. The firm market value of equity or market capitalization is obtained from Compustat and is calculated as the number of common shares outstanding (data item CSHO) multiplied by the close price at the fiscal year-end (data item PRCC_F). The second proxy is the ratio of R\&D expenses (data item LXRD) to the value of total assets (R\&D/BVA). The third proxy is defined as the common factor underlying the covariance among the variables MVA/BVA and R\&D/BVA and advertising expenses (data item LXAD), scaled by the book value of total assets and is obtained through principal components analysis.

Correlation is the slope coefficient from regressing firm stock return on the firm's peer group stock return. The peer group is constructed by matching the firm's size and industry to the other firms in the same industry and size quartile (excluding the firm itself). These regressions are run annually for each firm and the corresponding peer group using the last 24 months of data when available (a minimum of 12 months is required to run the regression). The peer group is updated every year.

The idiosyncratic risk is measured as the error variance from regressing firm stock return on the firm's peer group stock return as detailed above. The idiosyncratic variance is defined in terms of its cumulative distribution function so that it ranges between zero and one.

The difference between the date the CEO was assigned to the position (data field BECAMECEO in ExecuComp) and the year and month of the current fiscal year if the CEO is in office during the whole fiscal year. The natural log of the CEO's tenure is used when tenure is positive.

The CEO Tenure dummy equals one if the executive served as CEO for all or most of the indicated fiscal year (as identified by the data item CEOANN in Execucomp) and the CEO's tenure is less than one, and zero otherwise. Execucomp only retains the latest date for when the executive becomes the CEO for a particular company. In cases where the executive assumed the position of CEO for the same company at different points in time, the variable CEO Tenure has a negative value.

(i) A dummy that takes the value of one if the CEO is the board chair (as identified by the CEO title during the year) and zero otherwise; (ii) a dummy that takes the value of one if the $\mathrm{CEO}$ is involved in an interlocking relationship (ExecuComp data item INTERLOCK) requiring disclosure in the proxy statement; and (iii) a dummy variable that takes the value of one if the CEO share ownership is lower than the median for the year across CEOs in the sample.

Defined at either the four-digit GICS codes or the two-digit NAICS codes, depending on whether peer portfolios are constructed based on the GICS or the NAICS codes.

The log of the value of total equity shares owned plus the value of in-the-money options held by the CEO.

Calculated as the sum of the squared market shares of all the firms in the same industry-size groups of the firm. Industry is defined by the six-digit GICS code. 
TABLE 3

\section{Descriptive Statistics}

This table contains summary statistics for 3,885 unique CEOs and 2,457 unique firms. The primary dataset is the May $2009 \mathrm{ExecuComp}$ database released by Standard \& Poor's. The financial data is obtained from Compustat. The stock return data is obtained from the Center for Research in Securities Prices' (CRSP) monthly stock files. The inflation data is obtained from the CRSP-Indexes-U.S. Treasury and Inflation. All dollar values are in thousands (compensation) or millions (firm characteristics) of constant 1992 dollars. Returns are inflation adjusted. The idiosyncratic variance value is multiplied by 100. Firms are classified as High (Low) growth-options firms if the ratio of market value of assets to book value of assets is in the top (bottom) tercile of the distribution of all sample firms. All the variable means for the full sample are statistically significant at the one percent level.

\section{Panel A: Descriptive Statistics}

\begin{tabular}{|c|c|c|c|c|c|c|c|c|c|c|c|}
\hline \multirow{2}{*}{ Variables } & \multicolumn{3}{|c|}{$\begin{array}{c}\text { All Firms } \\
\mathrm{N}=15,557\end{array}$} & \multicolumn{3}{|c|}{$\begin{array}{l}\text { High Growth-Options Firms } \\
\qquad N=5,185\end{array}$} & \multicolumn{3}{|c|}{$\begin{array}{l}\text { Low Growth-Options Firms } \\
\qquad N=5,186\end{array}$} & \multicolumn{2}{|c|}{$\begin{array}{l}\text { High vs. Low GO } \\
\text { Differences in the }\end{array}$} \\
\hline & Mean & Std Dev & Median & Mean & Std Dev & Median & Mean & Std Dev & Median & T-stat. & $P$-value \\
\hline Cash Compensation & 1,223 & 1,612 & 854 & 1,216 & 1,734 & 861 & 1,203 & 1,372 & 817 & 0.45 & 0.00 \\
\hline Equity Compensation & 2,355 & 8,052 & 778 & 3,220 & 12,328 & 1,080 & 1,783 & 4,639 & 564 & 8.63 & 0.00 \\
\hline Total Flow Compensation & 3,840 & 8,688 & 2,034 & 4,712 & 12,832 & 2,405 & 3,271 & 5,759 & 1,701 & 7.89 & 0.00 \\
\hline Log of Total Flow Compensation & 7.6 & 1.1 & 7.6 & 7.8 & 1.2 & 7.8 & 7.5 & 1.0 & 7.4 & 11.44 & 0.00 \\
\hline Firm Stock Return & $2.2 \%$ & $36.6 \%$ & $6.1 \%$ & $-1.9 \%$ & $38.5 \%$ & $1.8 \%$ & $6.2 \%$ & $35.3 \%$ & $9.7 \%$ & -11.25 & 0.00 \\
\hline Industry-Size Portfolio Return & $6.0 \%$ & $25.4 \%$ & $9.0 \%$ & $3.0 \%$ & $26.6 \%$ & $6.2 \%$ & $8.9 \%$ & $24.3 \%$ & $11.5 \%$ & -11.70 & 0.00 \\
\hline Firm Size (Sales) & 3,894 & 10,831 & 1,002 & 3,835 & 12,436 & 765 & 3,997 & 10,104 & 1,227 & -0.73 & 0.00 \\
\hline Firm Size (Log of Sales) & 7.0 & 1.5 & 6.9 & 6.8 & 1.6 & 6.6 & 7.2 & 1.4 & 7.1 & -13.10 & 0.00 \\
\hline Market Capitalization & 5,995 & 18,196 & 1,314 & 9,163 & 24,557 & 1,859 & 4,103 & 11,413 & 1,024 & 14.33 & 0.00 \\
\hline Growth Options (MVA/BVA) & 1.9 & 1.2 & 1.5 & 3.2 & 1.4 & 2.7 & 1.1 & 0.1 & 1.1 & 143.38 & 0.00 \\
\hline Growth Options (R\&D/BVA) & $2.3 \%$ & $4.4 \%$ & $0 \%$ & $4.2 \%$ & $5.6 \%$ & $1.7 \%$ & $0.7 \%$ & $2.4 \%$ & $0.0 \%$ & 44.61 & 0.00 \\
\hline Growth Options (Factor) & 0.0 & 1.0 & -0.4 & 0.85 & 1.07 & 0.53 & -0.65 & 0.32 & -0.75 & 109.24 & 0.00 \\
\hline Correlation & 0.75 & 0.42 & 0.73 & 0.71 & 0.43 & 0.69 & 0.79 & 0.41 & 0.78 & -9.72 & 0.00 \\
\hline Idiosyncratic Variance & 0.975 & 4.370 & 0.576 & 1.13 & 1.57 & 0.69 & 0.89 & 5.23 & 0.49 & 3.68 & 0.00 \\
\hline CDF of Idiosyncratic Variance & 0.49 & 0.28 & 0.48 & 0.55 & 0.27 & 0.56 & 0.43 & 0.30 & 0.40 & 22.51 & 0.00 \\
\hline CEO Tenure & 7.5 & 7.3 & 5.3 & 8.2 & 7.7 & 5.8 & 6.9 & 6.8 & 4.9 & 8.85 & 0.00 \\
\hline Log CEO Tenure & 1.8 & 0.9 & 1.8 & 1.9 & 0.9 & 1.9 & 1.7 & 0.9 & 1.8 & 7.22 & 0.00 \\
\hline $\mathrm{Nr}$ of Firms in Peer Portfolio & 9.8 & 4.9 & 10.0 & 9.5 & 4.8 & 10.0 & 10.5 & 5.5 & 11.0 & -9.69 & 0.00 \\
\hline Herfindahl Index & $20.5 \%$ & $16.8 \%$ & $14.6 \%$ & $22.4 \%$ & $17.9 \%$ & $15.8 \%$ & $18.8 \%$ & $16.4 \%$ & $13.1 \%$ & 10.58 & 0.00 \\
\hline
\end{tabular}


TABLE 3 (Continued)

Descriptive Statistics

Panel B: Industry Breakdown

\begin{tabular}{|c|c|c|c|c|c|c|}
\hline Industry & GICS & Number & Percent & $\begin{array}{c}\text { M/B } \\
\text { Median }\end{array}$ & $\begin{array}{l}\mathrm{R} \& \mathrm{D} / \mathrm{A} \\
\text { Median }\end{array}$ & $\begin{array}{l}\text { Factor } \\
\text { Median }\end{array}$ \\
\hline Energy & 1010 & 831 & 5.34 & 1.58 & 0.00 & -0.50 \\
\hline Materials & 1510 & 1,274 & 8.19 & 1.39 & 0.01 & -0.48 \\
\hline Capital Goods & 2010 & 1,593 & 10.24 & 1.57 & 0.02 & -0.30 \\
\hline Commercial Services and Supplies & 2020 & 727 & 4.67 & 1.79 & 0.00 & -0.33 \\
\hline Transportation & 2030 & 409 & 2.63 & 1.36 & 0.00 & -0.64 \\
\hline Automobiles and Components & 2510 & 299 & 1.92 & 1.33 & 0.02 & -0.29 \\
\hline Consumer Durables and Apparel & 2520 & 919 & 5.91 & 1.44 & 0.00 & -0.38 \\
\hline Hotels, Restaurants, and Leisure & 2530 & 503 & 3.23 & 1.86 & 0.00 & -0.24 \\
\hline Media & 2540 & 275 & 1.77 & 1.91 & 0.00 & -0.31 \\
\hline Retailing & 2550 & 851 & 5.47 & 1.83 & 0.00 & -0.19 \\
\hline Food and Drug Retailing & 3010 & 224 & 1.44 & 1.55 & 0.00 & -0.46 \\
\hline Food, Beverage, and Tobacco & 3020 & 447 & 2.87 & 1.72 & 0.00 & -0.28 \\
\hline Household and Personal Products & 3030 & 137 & 0.88 & 2.53 & 0.02 & 0.60 \\
\hline Health Care Equipment and Services & 3510 & 1,059 & 6.81 & 2.08 & 0.00 & 0.02 \\
\hline Pharmaceuticals and Biotechnology & 3520 & 470 & 3.02 & 2.92 & 0.08 & 1.47 \\
\hline Banks & 4010 & 884 & 5.68 & 1.09 & 0.00 & -0.77 \\
\hline Diversified Financials & 4020 & 376 & 2.42 & 1.23 & 0.00 & -0.70 \\
\hline Insurance & 4030 & 573 & 3.68 & 1.11 & 0.00 & -0.77 \\
\hline Real Estate & 4040 & 187 & 1.20 & 1.41 & 0.00 & -0.61 \\
\hline Software and Services & 4510 & 816 & 5.25 & 2.37 & 0.07 & 1.06 \\
\hline Technology Hardware and Equipment & 4520 & 1,167 & 7.50 & 1.85 & 0.08 & 0.70 \\
\hline Semiconductors and Semiconductors Equipment & 4530 & 299 & 1.92 & 1.98 & 0.11 & 0.99 \\
\hline Telecommunication Services & 5010 & 142 & 0.91 & 1.69 & 0.00 & -0.46 \\
\hline Utilities & 5510 & 1,095 & 7.04 & 1.18 & 0.00 & -0.73 \\
\hline Full Sample & & 15,557 & 100 & 1.52 & 0.00 & -0.38 \\
\hline
\end{tabular}


TABLE 4

\section{Correlation Matrix}

This table presents the Spearman (Pearson) correlations in the upper (lower) diagonal. The sample has 15,557 observations covering the period of 1995 through 2008.

\begin{tabular}{|c|c|c|c|c|c|c|c|c|c|c|c|}
\hline Variables & $\begin{array}{c}\text { Log } \\
\text { Total } \\
\text { Comp. }\end{array}$ & $\begin{array}{c}\text { Firm } \\
\text { Stock } \\
\text { Ret. }\end{array}$ & $\begin{array}{c}\text { Peer } \\
\text { Stock } \\
\text { Ret. }\end{array}$ & Ln(Sales) & $\begin{array}{c}\mathrm{GO} \\
(\mathrm{MVA} / \mathrm{BVA})\end{array}$ & $\begin{array}{c}\mathrm{GO} \\
(\mathrm{R} \& \mathrm{D} / \mathrm{BVA})\end{array}$ & $\begin{array}{c}\mathrm{GO} \\
\text { (Factor) }\end{array}$ & $\begin{array}{l}\text { Idiosync. } \\
\text { Variance }\end{array}$ & Correlation & $\begin{array}{c}\text { CEO } \\
\text { Tenure }\end{array}$ & $\begin{array}{l}\text { Herfindahl } \\
\text { Index }\end{array}$ \\
\hline Log of Total Compensation & & $0.09 *$ & $-0.03 *$ & $0.59 *$ & $0.12 *$ & $0.05 *$ & $0.09 *$ & $-0.19 *$ & $0.09 *$ & $-0.03 *$ & $0.07 *$ \\
\hline Firm Stock Return & $0.08 *$ & & $0.53^{*}$ & $0.04 *$ & $-0.11^{*}$ & $-0.04 *$ & $-0.09 *$ & $-0.14 *$ & $-0.06^{*}$ & 0.00 & -0.00 \\
\hline Peer Stock Return & $-0.02 *$ & $0.51 *$ & & $-0.00 *$ & $-0.10^{*}$ & $-0.02 *$ & $-0.09 *$ & $-0.08 *$ & $0.02 *$ & 0.01 & -0.01 \\
\hline Firm Size (Log of Sales) & $0.34 *$ & -0.01 & -0.01 & & $-0.12 *$ & $-0.15^{*}$ & $-0.18^{*}$ & $-0.38^{*}$ & $0.07 *$ & $-0.09 *$ & $0.11 *$ \\
\hline Growth Options (MVA/BVA) & $0.08 *$ & $-0.09 *$ & $-0.09^{*}$ & $-0.02 *$ & & $0.38 *$ & $0.87 *$ & $0.14^{*}$ & $-0.09 *$ & $0.07 *$ & $0.15^{*}$ \\
\hline Growth Options (R\&D/BVA) & 0.01 & $-0.05^{*}$ & $-0.02 *$ & $-0.06^{*}$ & $0.36^{*}$ & & $0.67 *$ & $0.24 *$ & $-0.07 *$ & $-0.04 *$ & $0.10^{*}$ \\
\hline Growth Options (Factor) & $0.06^{*}$ & $-0.08 *$ & $-0.07^{*}$ & $-0.04 *$ & $0.84^{*}$ & $0.78^{*}$ & & $0.27 *$ & $-0.10^{*}$ & $0.03 *$ & $0.16^{*}$ \\
\hline Idiosyncratic Variance & $-0.04 *$ & $-0.04 *$ & $-0.02 *$ & $-0.04 *$ & $0.04 *$ & $0.07 *$ & $0.07 *$ & & $0.04 *$ & $0.03 *$ & $0.12 *$ \\
\hline Correlation & $0.08 *$ & $-0.08 *$ & $-0.02 *$ & -0.01 & $-0.03 *$ & $-0.02 *$ & $-0.04 *$ & $0.06^{*}$ & & 0.00 & $-0.17 *$ \\
\hline Log CEO Tenure & $-0.06^{*}$ & 0.00 & 0.00 & $-0.05^{*}$ & $0.07 *$ & -0.01 & $-0.04 *$ & 0.00 & -0.01 & & 0.01 \\
\hline Herfindahl Index & 0.00 & -0.01 & $-0.02 *$ & $0.10 *$ & $0.09 *$ & $0.03 *$ & $0.08 *$ & $0.02 *$ & $-0.13 *$ & 0.01 & \\
\hline
\end{tabular}

* Significant at the 5 percent level. 
TABLE 5

Regressions Estimating the Impact of Growth Options on RPE-Using six-digit GICS codes and size quartiles

Panel A. Regression of the Log of Total Flow Compensation

\begin{tabular}{|c|c|c|c|c|c|c|c|c|}
\hline \multirow{3}{*}{ Independent Variables } & \multirow{3}{*}{$\begin{array}{l}\text { Predicted } \\
\text { Sign } \\
\end{array}$} & \multirow[b]{3}{*}{$(1)$} & \multicolumn{6}{|c|}{ Growth-Options Proxy is } \\
\hline & & & \multicolumn{2}{|c|}{ MVA/BVA } & \multicolumn{2}{|c|}{ R\&D/BVA } & \multicolumn{2}{|c|}{ Factor } \\
\hline & & & $(2)$ & $(3)$ & (4) & $(5)$ & $(6)$ & $(7)$ \\
\hline Firm Stock Return & + & $\begin{array}{c}0.31 * * * \\
(9.14)\end{array}$ & $\begin{array}{c}0.31 * * * \\
(9.57)\end{array}$ & $\begin{array}{c}0.35 * * * \\
(10.83)\end{array}$ & $\begin{array}{c}0.24 * * * \\
(8.99)\end{array}$ & $\begin{array}{c}0.28 * * * \\
(9.65)\end{array}$ & $\begin{array}{c}0.29 * * * \\
(9.86)\end{array}$ & $\begin{array}{c}0.32 * * * \\
(10.50)\end{array}$ \\
\hline Firm Stock Return * Growth Options & + & & $\begin{array}{c}-0.01 \\
(-0.28)\end{array}$ & $\begin{array}{c}-0.00 \\
(-0.18)\end{array}$ & $\begin{array}{c}-1.26 * * \\
(-2.46)\end{array}$ & $\begin{array}{l}-0.99 * \\
(-1.88)\end{array}$ & $\begin{array}{l}-0.06 * \\
(-1.93)\end{array}$ & $\begin{array}{c}-0.05 \\
(-1.59)\end{array}$ \\
\hline Firm Stock Return * Id. Variance & - & & & $\begin{array}{c}-0.20 * * \\
(-2.24)\end{array}$ & & $\begin{array}{c}-0.19 * * \\
(-2.02)\end{array}$ & & $\begin{array}{l}-0.18 * \\
(-1.95)\end{array}$ \\
\hline Firm Stock Return * Log CEO Tenure & + & & & $\begin{array}{c}0.09 * * * \\
(3.24)\end{array}$ & & $\begin{array}{c}0.11 * * * \\
(3.93)\end{array}$ & & $\begin{array}{c}0.10^{* * *} \\
(3.45)\end{array}$ \\
\hline Firm Stock Return * Herfindahl Index & $?$ & & & $\begin{array}{c}-0.05 \\
(-0.42)\end{array}$ & & $\begin{array}{c}-0.08 \\
(-0.67)\end{array}$ & & $\begin{array}{c}-0.05 \\
(-0.42)\end{array}$ \\
\hline Peer Stock Return & - & $\begin{array}{c}-0.08 * * \\
(-2.30)\end{array}$ & $\begin{array}{c}-0.09 * * * \\
(-2.77)\end{array}$ & $\begin{array}{c}-0.13 * * * \\
(-3.78)\end{array}$ & $\begin{array}{c}-0.11 * * * \\
(-3.29)\end{array}$ & $\begin{array}{c}-0.14 * * * \\
(-4.14)\end{array}$ & $\begin{array}{c}-0.11 * * * \\
(-3.30)\end{array}$ & $\begin{array}{r}-0.14 * * * \\
(-4.05)\end{array}$ \\
\hline Peer Stock Return * Growth Options & $?$ & & $\begin{array}{c}0.08 * * * \\
(2.89)\end{array}$ & $\begin{array}{c}0.08 * * * \\
(2.80)\end{array}$ & $\begin{array}{l}1.61 * * \\
(2.57)\end{array}$ & $\begin{array}{l}1.41 * * \\
(2.18)\end{array}$ & $\begin{array}{c}0.12 * * * \\
(3.47)\end{array}$ & $\begin{array}{c}0.12 * * * \\
(3.29)\end{array}$ \\
\hline Peer Stock Return * Correlation & - & & & $\begin{array}{c}-0.17 * * \\
(-2.47)\end{array}$ & & $\begin{array}{c}-0.19 * * * \\
(-2.59)\end{array}$ & & $\begin{array}{c}-0.17 * * \\
(-2.46)\end{array}$ \\
\hline Peer Stock Return * Id. Variance & - & & & $\begin{array}{c}0.18 \\
(1.64)\end{array}$ & & $\begin{array}{c}0.16 \\
(1.33)\end{array}$ & & $\begin{array}{c}0.10 \\
(0.94)\end{array}$ \\
\hline Peer Stock Return * Log CEO Tenure & $?$ & & & $\begin{array}{c}-0.03 \\
(-0.95)\end{array}$ & & $\begin{array}{c}-0.04 \\
(-1.08)\end{array}$ & & $\begin{array}{c}-0.03 \\
(-0.89)\end{array}$ \\
\hline Peer Stock Return * Herfindahl Index & + & & & $\begin{array}{c}-0.01 \\
(-0.05)\end{array}$ & & $\begin{array}{c}0.02 \\
(0.11)\end{array}$ & & $\begin{array}{c}0.01 \\
(0.09)\end{array}$ \\
\hline GO Proxy & & $\begin{array}{c}0.16 * * * \\
(7.36)\end{array}$ & $\begin{array}{c}0.16 * * * \\
(7.34)\end{array}$ & $\begin{array}{c}0.16 * * * \\
(7.12)\end{array}$ & $\begin{array}{c}-0.45 \\
(-0.70)\end{array}$ & $\begin{array}{c}-0.43 \\
(-0.68)\end{array}$ & $\begin{array}{c}0.21 * * * \\
(6.32)\end{array}$ & $\begin{array}{c}0.20 * * * \\
(6.21)\end{array}$ \\
\hline Correlation & & & & $\begin{array}{c}0.02 \\
(0.90)\end{array}$ & & $\begin{array}{c}0.03 \\
(1.24)\end{array}$ & & $\begin{array}{c}0.02 \\
(1.02)\end{array}$ \\
\hline Herfindahl Index & & & & $\begin{array}{c}0.07 \\
(0.89)\end{array}$ & & $\begin{array}{c}0.08 \\
(1.01)\end{array}$ & & $\begin{array}{c}0.07 \\
(0.96)\end{array}$ \\
\hline Firm Size (Log of Sales) & & $\begin{array}{c}0.22 * * * \\
(6.29)\end{array}$ & $\begin{array}{c}0.23 * * * \\
(6.36)\end{array}$ & $\begin{array}{c}0.22 * * * \\
(6.28)\end{array}$ & $\begin{array}{c}0.19 * * * \\
(5.68)\end{array}$ & $\begin{array}{c}0.19 * * * \\
(5.60)\end{array}$ & $\begin{array}{c}0.22 * * * \\
(6.21)\end{array}$ & $\begin{array}{c}0.22 * * * \\
(6.12)\end{array}$ \\
\hline Dummy CEO Tenure & & $\begin{array}{c}0.40 * * * \\
(7.34)\end{array}$ & $\begin{array}{c}0.40 * * * \\
(7.33)\end{array}$ & $\begin{array}{c}0.40 * * * \\
(7.39)\end{array}$ & $\begin{array}{c}0.41 * * * \\
(7.39)\end{array}$ & $\begin{array}{c}0.41 * * * \\
(7.46)\end{array}$ & $\begin{array}{c}0.41 * * * \\
(7.49)\end{array}$ & $\begin{array}{c}0.42 * * * \\
(7.55)\end{array}$ \\
\hline Log CEO Tenure & & $\begin{array}{c}0.21 * * * \\
(5.17)\end{array}$ & $\begin{array}{c}0.21 * * * \\
(5.13)\end{array}$ & $\begin{array}{c}0.21 * * * \\
(4.96)\end{array}$ & $\begin{array}{c}0.22 * * * \\
(5.26)\end{array}$ & $\begin{array}{c}0.21 * * * \\
(5.05)\end{array}$ & $\begin{array}{c}0.22 * * * \\
(5.31)\end{array}$ & $\begin{array}{c}0.21 * * * \\
(5.11)\end{array}$ \\
\hline Idiosyncratic Variance & & $\begin{array}{c}-0.07 \\
(-1.45)\end{array}$ & $\begin{array}{c}-0.07 \\
(-1.51)\end{array}$ & $\begin{array}{c}-0.07 \\
(-1.50)\end{array}$ & $\begin{array}{l}-0.08^{*} \\
(-1.70)\end{array}$ & $\begin{array}{l}-0.08^{*} \\
(-1.70)\end{array}$ & $\begin{array}{l}-0.09 * \\
(-1.79)\end{array}$ & $\begin{array}{l}-0.09 * \\
(-1.71)\end{array}$ \\
\hline Dummy CEO Chair & & $\begin{array}{c}0.04 \\
(1.37)\end{array}$ & $\begin{array}{c}0.04 \\
(1.45)\end{array}$ & $\begin{array}{c}0.04 \\
(1.45)\end{array}$ & $\begin{array}{l}0.05^{*} \\
(1.74)\end{array}$ & $\begin{array}{l}0.05 * \\
(1.72)\end{array}$ & $\begin{array}{c}0.05 \\
(1.55)\end{array}$ & $\begin{array}{c}0.05 \\
(1.55)\end{array}$ \\
\hline Dummy CEO Ownership & & $\begin{array}{c}-0.00 \\
(-0.16)\end{array}$ & $\begin{array}{c}-0.00 \\
(-0.12)\end{array}$ & $\begin{array}{c}-0.00 \\
(-0.06)\end{array}$ & $\begin{array}{c}-0.01 \\
(-0.34)\end{array}$ & $\begin{array}{c}-0.01 \\
(-0.27)\end{array}$ & $\begin{array}{c}-0.00 \\
(-0.12)\end{array}$ & $\begin{array}{c}-0.00 \\
(-0.07)\end{array}$ \\
\hline Dummy Interlock & & $\begin{array}{c}0.04 \\
(0.70)\end{array}$ & $\begin{array}{c}0.04 \\
(0.70)\end{array}$ & $\begin{array}{c}0.04 \\
(0.69)\end{array}$ & $\begin{array}{c}0.05 \\
(0.77)\end{array}$ & $\begin{array}{c}0.05 \\
(0.77)\end{array}$ & $\begin{array}{c}0.05 \\
(0.78)\end{array}$ & $\begin{array}{c}0.05 \\
(0.79)\end{array}$ \\
\hline CEO Fixed Effects & & Yes & Yes & Yes & Yes & Yes & Yes & Yes \\
\hline Year and Industry Dummies & & Yes & Yes & Yes & Yes & Yes & Yes & Yes \\
\hline Number of Observations & & 15,557 & 15,557 & 15,557 & 15,557 & 15,557 & 15,557 & 15,557 \\
\hline Adjusted $\mathrm{R}^{2}$ & & $73.13 \%$ & $73.17 \%$ & $73.25 \%$ & $72.41 \%$ & $72.51 \%$ & $72.90 \%$ & $72.99 \%$ \\
\hline
\end{tabular}


TABLE 5 (Continued)

Regressions Estimating the Impact of Growth Options on RPE - Using six-digit GICS codes and size quartiles

Panel B. Test of Hypotheses

\begin{tabular}{|c|c|c|c|c|c|c|c|}
\hline \multirow{3}{*}{ Hypotheses tests } & & \multicolumn{6}{|c|}{ " Growth-Options Proxy is } \\
\hline & & \multicolumn{2}{|c|}{ MVA/BVA } & \multicolumn{2}{|c|}{$\mathrm{R} \& \mathrm{D} / \mathrm{BVA}$} & \multicolumn{2}{|c|}{ Factor } \\
\hline & & $(2)$ & (3) & (4) & $(5)$ & $(6)$ & $(7)$ \\
\hline Estimated RPE Value & & -0.30 & -0.37 & -0.46 & -0.52 & -0.38 & -0.43 \\
\hline $\mathrm{H}_{0}: \alpha_{2} / \alpha_{1} \geq 0, \mathrm{H}_{\mathrm{a}}: \alpha_{2} / \alpha_{1}<0$ & $p$-value & $(0.00)$ & $(0.00)$ & $(0.00)$ & $(0.00)$ & $(0.00)$ & $(0.00)$ \\
\hline Estimated RPE Value for High GO & & -0.23 & -0.31 & -0.45 & -0.50 & -0.26 & -0.33 \\
\hline $\mathrm{H}_{0}: \alpha_{2} / \alpha_{1} \geq 0, \mathrm{H}_{\mathrm{a}}: \alpha_{2} / \alpha_{1}<0$ & $p$-value & $(0.02)$ & $(0.00)$ & $(0.00)$ & $(0.00)$ & $(0.02)$ & $(0.00)$ \\
\hline Estimated RPE Value for Low $G O$ & & -0.49 & -0.53 & -0.55 & -0.59 & -0.59 & -0.61 \\
\hline $\mathrm{H}_{0}: \alpha_{2} / \alpha_{1} \geq 0, \mathrm{H}_{\mathrm{a}}: \alpha_{2} / \alpha_{1}<0$ & $p$-value & $(0.00)$ & $(0.00)$ & $(0.00)$ & $(0.00)$ & $(0.00)$ & $(0.00)$ \\
\hline
\end{tabular}

Panel C. Distribution of RPE

\begin{tabular}{clcccc}
\hline \hline \multirow{2}{*}{ GICS } & \multicolumn{1}{c}{ Description } & $\begin{array}{c}\text { Nr. } \\
\text { Observations }\end{array}$ & Mean RPE & Median RPE & Std. Dev. \\
\hline 55 & Utilities & 1,095 & -0.62 & -0.61 & 0.22 \\
40 & Financials & 2,020 & -0.59 & -0.60 & 0.29 \\
10 & Energy & 831 & -0.51 & -0.52 & 0.24 \\
15 & Materials & 1274 & -0.49 & -0.49 & 0.32 \\
20 & Industrials & 2,729 & -0.37 & -0.40 & 0.42 \\
50 & Telecommunication & 142 & -0.35 & -0.37 & 0.39 \\
& Services & & & & \\
30 & Consumer Discretionary & 2,847 & -0.30 & -0.36 & 0.44 \\
45 & Consumer Staples & 808 & -0.21 & -0.27 & 0.42 \\
35 & Information Technology & 2,282 & -0.09 & -0.20 & 0.66 \\
\hline \hline
\end{tabular}

Panel A: This panel estimates the following equation: $W_{i t}=\eta_{0}+\eta_{1} \operatorname{Ret}_{i t}+\eta_{2} \operatorname{Ret}_{i t} G O+\sum \eta_{5-7} \operatorname{Ret}_{i t} \times$ FirmChar $_{i t}+\eta_{3} \operatorname{Ret}_{\mathrm{pt}}+\eta_{4} \operatorname{Ret}_{\mathrm{it}} \mathrm{GO}+\sum \eta_{8-11} \operatorname{Ret}_{\mathrm{pt}} \times \mathrm{FirmChar}_{\mathrm{it}}$ $+\eta$ ControlVariables ${ }_{i t}+u_{i t}$. The natural $\log (\ln )$ of the real total CEO compensation $\left(\mathrm{W}_{\mathrm{i}}\right)$ is regressed on the firm's performance $\left(\operatorname{Ret}_{\mathrm{i}}\right)$, the peer group performance $\left(\right.$ Ret $\left._{\mathrm{p}}\right)$, and the control variables. The control variables included are the lagged value of the firm's level of growth options, the correlation between the performance of the firm and the peer group the firm belongs to, the Herfindahl index, firm size, the ln of CEO tenure, a dummy if CEO's tenure is missing or negative, the firm's idiosyncratic variance, governance measures, and year and industry dummies. The firm characteristics used in the interaction term with the firm's performance are the firm's level of growth options, the idiosyncratic variance of the firm's stock return with respect to the peer performance, CEO tenure, and the Herfindahl index. The firm characteristics used in the interaction term with the peer's performance are the same as the ones used in the interaction term with the firm's performance plus the firm's correlation with respect to the peer performance. All of the firm characteristics used in the interaction terms are mean-centered. The variables are defined in Table 2. All of the dollar values are in thousands (compensation) or millions (firm characteristics) of constant 1992 dollars. The standard errors are corrected for heteroskedasticity by using the HuberWhite correction and clustered by firm. T-tests in Panel A are reported in parentheses under each estimated coefficient. The symbols *, **, and *** correspond to 10 percent, 5 percent, and 1 percent significance levels, respectively, for two-tailed t-tests. Sample: ExecuComp database for the years 1995-2008 merged with Compustat and CRSP.

Panel B: This panel reports the $p$-values for each of the tests performed. Please refer to the paper for a detailed explanation of these tests. The variables $\alpha_{1}$ and $\alpha_{2}$ are defined as $\alpha_{1}=\eta_{1}+\eta_{2} \mathrm{GO}+\eta_{5}$ Id.Var $+\eta_{6}$ CEOTenure $+\eta_{7}$ HerfindahlIndex and $\alpha_{2}=\eta_{3}+\eta_{4} \mathrm{GO}+\eta_{8}$ Correlation $+\eta_{9}$ Id.Var $+\eta_{10} \mathrm{CEOTenure}$ $+\eta_{11}$ HerfindahlIndex. The estimated coefficients $\eta$ are the ones obtained from Table 5, Panel A, and the firm characteristics are evaluated at their meancentered values, which are zero. The hypotheses tests for the high (low) GO firms are evaluated at the 75 percent (25 percent) value of the meancentered GO distribution.

Panel C: The RPE measure is constructed using the coefficients estimated from the regression in Column (3) of Panel A in this table and the meancentered firm characteristics for each firm-year observation. The estimated RPE measure for each firm $i$ at time $t$ is calculated as $\mathrm{RPE}_{\mathrm{it}}=\left[\eta_{3}+\sum \eta \times\right.$ FirmChar $\left._{\mathrm{it}}\right] /\left[\eta_{1}+\sum \eta \times\right.$ FirmChar $\left._{\mathrm{it}}\right]$. The GO proxy used is the ratio of the market-to-book value of assets. The results are similar using $\mathrm{R} \& \mathrm{D}$ expenses scaled by assets as the GO proxy. The table shows the distribution of the estimated RPE measure across firms within a two-digit GICS code. 
TABLE 6

Regressions Estimating the Impact of Growth Options on RPE using six-digit GICS codes and GO quartiles

\begin{tabular}{|c|c|c|c|c|c|c|c|c|}
\hline \multirow{3}{*}{ Independent Variables } & \multirow{3}{*}{$\begin{array}{l}\text { Predicted } \\
\text { Sign }\end{array}$} & \multirow[b]{3}{*}{ (1) } & \multicolumn{6}{|c|}{ Growth-Options Proxy is } \\
\hline & & & \multicolumn{2}{|c|}{ MVA/BVA } & \multicolumn{2}{|c|}{$\mathrm{R} \& \mathrm{D} / \mathrm{BVA}$} & \multicolumn{2}{|c|}{ Factor } \\
\hline & & & (2) & (3) & $(4)$ & $(5)$ & $(6)$ & $(7)$ \\
\hline Firm Stock Return & + & $\begin{array}{c}0.32 * * * \\
(8.80)\end{array}$ & $\begin{array}{c}0.33 * * * \\
(9.30)\end{array}$ & $\begin{array}{c}0.38 * * * \\
(12.25)\end{array}$ & $\begin{array}{c}0.26 * * * \\
(8.61)\end{array}$ & $\begin{array}{c}0.31 * * * \\
(11.00)\end{array}$ & $\begin{array}{c}0.30 * * * \\
(9.67)\end{array}$ & $\begin{array}{c}0.35 * * * \\
(12.10)\end{array}$ \\
\hline Firm Stock Return * Growth Options & + & & $\begin{array}{l}-0.00 \\
(-0.09)\end{array}$ & $\begin{array}{c}0.00 \\
(0.02)\end{array}$ & $\begin{array}{c}-1.30 * * \\
(-2.25)\end{array}$ & $\begin{array}{l}-1.02^{*} \\
(-1.76)\end{array}$ & $\begin{array}{l}-0.06^{*} \\
(-1.88)\end{array}$ & $\begin{array}{l}-0.05 \\
(-1.56)\end{array}$ \\
\hline Firm Stock Return * Id. Variance & - & & & $\begin{array}{c}-0.29 * * * \\
(-2.96)\end{array}$ & & $\begin{array}{c}-0.29 * * * \\
(-2.95)\end{array}$ & & $\begin{array}{c}-0.27 * * * \\
(-2.85)\end{array}$ \\
\hline Firm Stock Return * Log CEO Tenure & + & & & $\begin{array}{c}0.10^{* * * *} \\
(3.24)\end{array}$ & & $\begin{array}{c}0.11 * * * \\
(3.77)\end{array}$ & & $\begin{array}{c}0.10 * * * \\
(3.44)\end{array}$ \\
\hline Firm Stock Return * Herfindahl Index & $?$ & & & $\begin{array}{l}-0.08 \\
(-0.67)\end{array}$ & & $\begin{array}{c}-0.12 \\
(-1.06)\end{array}$ & & $\begin{array}{c}-0.08 \\
(-0.75)\end{array}$ \\
\hline Peer Stock Return & - & $\begin{array}{c}-0.07 \\
(-1.39)\end{array}$ & $\begin{array}{l}-0.08^{*} \\
(-1.79)\end{array}$ & $\begin{array}{c}-0.11 * * * \\
(-2.83)\end{array}$ & $\begin{array}{c}-0.10 * * * \\
(-2.27)\end{array}$ & $\begin{array}{c}-0.13 * * * \\
(-3.23)\end{array}$ & $\begin{array}{c}-0.10 * * \\
(-2.34)\end{array}$ & $\begin{array}{c}-0.12 * * * \\
(-3.17)\end{array}$ \\
\hline Peer Stock Return * Growth Options & $?$ & & $\begin{array}{c}0.11 * * * \\
(3.19)\end{array}$ & $\begin{array}{c}0.10 * * * \\
(3.11)\end{array}$ & $\begin{array}{c}2.11 * * \\
(2.42)\end{array}$ & $\begin{array}{c}2.17 * * * \\
(2.60)\end{array}$ & $\begin{array}{c}0.16^{* * * *} \\
(3.42)\end{array}$ & $\begin{array}{c}0.16^{* * *} \\
(3.60)\end{array}$ \\
\hline Peer Stock Return * Correlation & - & & & $\begin{array}{c}-0.15 \\
(-1.57)\end{array}$ & & $\begin{array}{l}-0.19^{*} \\
(-1.92)\end{array}$ & & $\begin{array}{l}-0.16 \\
(-1.62)\end{array}$ \\
\hline Peer Stock Return * Id. Variance & - & & & $\begin{array}{c}0.09 \\
(0.57)\end{array}$ & & $\begin{array}{c}0.03 \\
(0.21)\end{array}$ & & $\begin{array}{c}0.00 \\
(0.02)\end{array}$ \\
\hline Peer Stock Return * Log CEO Tenure & $?$ & & & $\begin{array}{c}-0.02 \\
(-0.42)\end{array}$ & & $\begin{array}{l}-0.02 \\
(-0.44)\end{array}$ & & $\begin{array}{c}-0.02 \\
(-0.43)\end{array}$ \\
\hline Peer Stock Return * Herfindahl Index & + & & & $\begin{array}{c}0.05 \\
(0.31)\end{array}$ & & $\begin{array}{c}0.11 \\
(0.70)\end{array}$ & & $\begin{array}{c}0.09 \\
(0.57)\end{array}$ \\
\hline GO Proxy & & $\begin{array}{c}0.16 * * * \\
(7.77)\end{array}$ & $\begin{array}{c}0.16^{* * *} \\
(8.03)\end{array}$ & $\begin{array}{c}0.16^{* * *} \\
(7.77)\end{array}$ & $\begin{array}{c}-0.47 \\
(-0.75)\end{array}$ & $\begin{array}{c}-0.44 \\
(-0.70)\end{array}$ & $\begin{array}{c}0.21 * * * \\
(7.10)\end{array}$ & $\begin{array}{c}0.21 * * * \\
(6.99)\end{array}$ \\
\hline Correlation & & & & $\begin{array}{c}0.03 \\
(1.26)\end{array}$ & & $\begin{array}{c}0.03 \\
(1.54)\end{array}$ & & $\begin{array}{c}0.03 \\
(1.50)\end{array}$ \\
\hline Herfindahl Index & & & & $\begin{array}{c}0.06 \\
(0.78)\end{array}$ & & $\begin{array}{c}0.06 \\
(0.76)\end{array}$ & & $\begin{array}{l}0.06 \\
(0.81)\end{array}$ \\
\hline Log CEO Tenure & & $\begin{array}{c}0.21 * * * \\
(5.08)\end{array}$ & $\begin{array}{c}0.21 * * * \\
(5.06)\end{array}$ & $\begin{array}{c}0.21 * * * \\
(4.89)\end{array}$ & $\begin{array}{c}0.22 * * * \\
(5.16)\end{array}$ & $\begin{array}{c}0.21 * * * \\
(4.99)\end{array}$ & $\begin{array}{c}0.22 * * * \\
(5.20)\end{array}$ & $\begin{array}{c}0.21 * * * \\
(5.04)\end{array}$ \\
\hline Idiosyncratic Variance & & $\begin{array}{c}-0.05 \\
(-1.03)\end{array}$ & $\begin{array}{l}-0.06 \\
(-1.17)\end{array}$ & $\begin{array}{c}-0.05 \\
(-0.94)\end{array}$ & $\begin{array}{c}-0.06 \\
(-1.20)\end{array}$ & $\begin{array}{c}-0.05 \\
(-0.98)\end{array}$ & $\begin{array}{c}-0.07 \\
(-1.45)\end{array}$ & $\begin{array}{c}-0.07 \\
(-1.18)\end{array}$ \\
\hline Control Variables & & Yes & Yes & Yes & Yes & Yes & Yes & Yes \\
\hline CEO Fixed Effects & & Yes & Yes & Yes & Yes & Yes & Yes & Yes \\
\hline Year and Industry Dummies & & Yes & Yes & Yes & Yes & Yes & Yes & Yes \\
\hline Number of Observations & & 14,956 & 14,956 & 14,956 & 14,956 & 14,956 & 14,956 & 14,956 \\
\hline Adjusted $\mathrm{R}^{2}$ & & $73.35 \%$ & $73.43 \%$ & $73.53 \%$ & $72.63 \%$ & $72.77 \%$ & $73.16 \%$ & $73.28 \%$ \\
\hline
\end{tabular}

This table estimates the following equation: $W_{i t}=\eta_{0}+\eta_{1}$ Ret $_{i t}+\eta_{2}$ Ret $_{i t} G O+\sum \eta_{5-7} \operatorname{Ret}_{i t} \times$ FirmChar $_{i t}+\eta_{3} \operatorname{Ret}_{\mathrm{pt}}+\eta_{4}$ Ret $_{\mathrm{it}} \mathrm{GO}+\sum \eta_{8-11}$ Ret $_{\mathrm{pt}} \times \mathrm{FirmChar}_{i t}$

$+\eta$ ControlVariables ${ }_{i t}+u_{i t}$. The variables are defined in Table 2. The standard errors are corrected for heteroskedasticity by using the Huber-White correction and clustered by firm. The symbols ***, and *** correspond to 10 percent, 5 percent, and 1 percent significance levels, respectively, for twotailed t-tests. Sample: ExecuComp database for the years 1995-2008 merged with Compustat and CRSP. 
TABLE 7

Regressions Estimating the Impact of Growth Options on RPE using three-digit NAICS codes and size quartiles

\begin{tabular}{|c|c|c|c|c|c|c|c|c|}
\hline \multirow{3}{*}{ Independent Variables } & \multirow{3}{*}{$\begin{array}{c}\text { Predicted } \\
\text { Sign } \\
\end{array}$} & \multirow[b]{3}{*}{ (1) } & \multicolumn{6}{|c|}{ Growth-Options Proxy is } \\
\hline & & & \multicolumn{2}{|c|}{ MVA/BVA } & \multicolumn{2}{|c|}{$\mathrm{R} \& \mathrm{D} / \mathrm{BVA}$} & \multicolumn{2}{|c|}{ Factor } \\
\hline & & & (2) & $(3)$ & (4) & $(5)$ & $(6)$ & (7) \\
\hline \multirow[t]{2}{*}{ Firm Stock Return } & + & $0.30 * * *$ & $0.30 * * *$ & $0.34 * * *$ & $0.24 * * *$ & $0.28 * * *$ & $0.28 * * *$ & $0.32 * * *$ \\
\hline & & $(13.13)$ & $(13.56)$ & (13.99) & (11.91) & $(12.10)$ & $(13.21)$ & $(13.27)$ \\
\hline \multirow[t]{2}{*}{ Firm Stock Return * Growth Options } & + & & -0.00 & 0.00 & $-0.89 * *$ & $-0.76^{* *}$ & $-0.04 *$ & -0.03 \\
\hline & & & $(-0.00)$ & $(0.23)$ & $(-2.51)$ & $(-2.04)$ & $(-1.79)$ & $(-1.33)$ \\
\hline \multirow{2}{*}{ Firm Stock Return * Id. Variance } & - & & & $-0.17 * *$ & & $-0.16^{* *}$ & & $-0.17 * *$ \\
\hline & & & & $(-2.43)$ & & $(-2.19)$ & & $(-2.38)$ \\
\hline \multirow{2}{*}{ Firm Stock Return * Log CEO Tenure } & + & & & $0.04 *$ & & $0.05 * *$ & & $0.05 * *$ \\
\hline & & & & $(1.84)$ & & $(2.42)$ & & $(2.18)$ \\
\hline \multirow[t]{2}{*}{ Firm Stock Return * Herfindahl Index } & $?$ & & & 0.01 & & -0.06 & & -0.01 \\
\hline & & & & $(0.10)$ & & $(-0.51)$ & & $(-0.06)$ \\
\hline \multirow{2}{*}{ Peer Stock Return } & - & $-0.09 * * *$ & $-0.10 * * *$ & $-0.13 * * *$ & $-0.10 * * *$ & $-0.13 * * *$ & $-0.11 * * *$ & $-0.13 * * *$ \\
\hline & & $(-3.01)$ & $(-3.35)$ & $(-3.87)$ & $(-3.25)$ & $(-3.80)$ & $(-3.58)$ & $(-4.08)$ \\
\hline \multirow[t]{2}{*}{ Peer Stock Return * Growth Options } & $?$ & & $0.06^{* *}$ & $0.06^{* *}$ & $1.49 * * *$ & $2.17 * * *$ & $0.07 * *$ & $0.10 * * *$ \\
\hline & & & $(2.36)$ & $(2.55)$ & $(2.88)$ & $(3.98)$ & $(2.51)$ & $(3.25)$ \\
\hline \multirow{2}{*}{ Peer Stock Return * Correlation } & - & & & $-0.10^{*}$ & & $-0.11 * *$ & & $-0.11 * *$ \\
\hline & & & & $(-1.81)$ & & $(-1.97)$ & & $(-2.10)$ \\
\hline \multirow[t]{2}{*}{ Peer Stock Return * Id. Variance } & - & & & -0.05 & & -0.14 & & -0.12 \\
\hline & & & & $(-0.58)$ & & $(-1.53)$ & & $(-1.32)$ \\
\hline \multirow{2}{*}{ Peer Stock Return * Log CEO Tenure } & $?$ & & & 0.01 & & 0.01 & & 0.01 \\
\hline & & & & $(0.41)$ & & $(0.50)$ & & $(0.27)$ \\
\hline \multirow{2}{*}{ Peer Stock Return * Herfindahl Index } & + & & & 0.01 & & 0.19 & & 0.10 \\
\hline & & & & $(0.04)$ & & $(1.33)$ & & $(0.72)$ \\
\hline \multirow[t]{2}{*}{ GO Proxy } & & $0.15^{* * *}$ & $0.15^{* * *}$ & $0.15 * * *$ & $-0.95^{*}$ & $-0.91 *$ & $0.19 * * *$ & $0.19 * * *$ \\
\hline & & $(11.16)$ & $(11.16)$ & (11.03) & $(-1.83)$ & $(-1.75)$ & $(9.27)$ & $(9.27)$ \\
\hline \multirow{2}{*}{ Correlation } & & & & $0.03 *$ & & 0.03 & & $0.03 *$ \\
\hline & & & & $(1.83)$ & & $(1.40)$ & & $(1.76)$ \\
\hline \multirow[t]{2}{*}{ Herfindahl Index } & & & & -0.03 & & 0.04 & & -0.01 \\
\hline & & & & $(-0.24)$ & & $(0.37)$ & & $(-0.06)$ \\
\hline \multirow[t]{2}{*}{ Log CEO Tenure } & & $0.22 * * *$ & $0.22 * * *$ & $0.21 * * *$ & $0.22 * * *$ & $0.22 * * *$ & $0.23 * * *$ & $0.22 * * *$ \\
\hline & & $(6.52)$ & $(6.52)$ & $(6.27)$ & $(6.59)$ & $(6.32)$ & $(6.71)$ & $(6.45)$ \\
\hline \multirow[t]{2}{*}{ Idiosyncratic Variance } & & -0.03 & -0.03 & -0.02 & -0.01 & -0.01 & -0.03 & -0.03 \\
\hline & & $(-0.60)$ & $(-0.59)$ & $(-0.51)$ & $(-0.25)$ & $(-0.11)$ & $(-0.69)$ & $(-0.56)$ \\
\hline Control Variables & & Yes & Yes & Yes & Yes & Yes & Yes & Yes \\
\hline CEO Fixed Effects & & Yes & Yes & Yes & Yes & Yes & Yes & Yes \\
\hline Year and Industry Dummies & & Yes & Yes & Yes & Yes & Yes & Yes & Yes \\
\hline Number of Observations & & 21,660 & 21,660 & 21,660 & 21,660 & 21,660 & 21,660 & 21,660 \\
\hline Adjusted $\mathrm{R}^{2}$ & & $73.31 \%$ & $73.33 \%$ & $73.37 \%$ & $72.52 \%$ & $72.59 \%$ & $72.99 \%$ & $73.05 \%$ \\
\hline
\end{tabular}

This table estimates the following equation: $\mathrm{W}_{\mathrm{it}}=\eta_{0}+\eta_{1}$ Ret $_{\mathrm{it}}+\eta_{2}$ Ret $_{\mathrm{it}} \mathrm{GO}+\sum \eta_{5-7} \operatorname{Ret}_{\mathrm{it}} \times$ FirmChar $_{i t}+\eta_{3} \operatorname{Ret}_{\mathrm{pt}}+\eta_{4} \operatorname{Ret}_{\mathrm{it}} \mathrm{GO}+\sum \eta_{8-11} \operatorname{Ret}_{\mathrm{pt}} \times \mathrm{FirmChar}_{i t}$ $+\eta$ ControlVariables ${ }_{i t}+u_{i t}$. The variables are defined in Table 2. The standard errors are corrected for heteroskedasticity by using the Huber-White correction and clustered by firm. The symbols *,**, and *** correspond to 10 percent, 5 percent, and 1 percent significance levels, respectively, for twotailed t-tests. Sample: ExecuComp database for the years 1995-2008 merged with Compustat and CRSP. 
TABLE 8

Descriptive Statistics on Relative Performance Evaluation use from Firm's Proxy Statement

\begin{tabular}{|c|c|c|c|c|c|c|}
\hline & \multicolumn{2}{|c|}{ All Firms } & \multicolumn{2}{|c|}{$\bar{~}_{\text {High GO Firms }}{ }^{(a)}$} & \multicolumn{2}{|c|}{ "Low GO Firms ${ }^{(a)}$} \\
\hline & Nr Firms & $\%$ & Nr Firms & $\%$ & Nr Firms & $\%$ \\
\hline Observations for fiscal year of 2006-2008 & 1,714 & $100.0 \%$ & 571 & $100.0 \%$ & 572 & $100.0 \%$ \\
\hline Firms that explicitly state using RPE & 489 & $28.5 \%$ & 122 & $21.4 \%$ & 199 & $34.8 \%$ \\
\hline Firms that explicitly state using RPE \& disclose peers or disclose using an index & 470 & $27.4 \%$ & 119 & $20.8 \%$ & 193 & $33.7 \%$ \\
\hline Firms that explicitly state using RPE \& disclose peers & 331 & $19.3 \%$ & 85 & $14.9 \%$ & 134 & $23.4 \%$ \\
\hline Firms that explicitly state using RPE \& disclose using an index & 180 & $10.5 \%$ & 43 & $7.5 \%$ & 71 & $12.4 \%$ \\
\hline
\end{tabular}

Panel B: Number of peers disclosed for the sample of firms that use RPE and disclose peers

\begin{tabular}{|c|c|c|c|c|}
\hline & $\mathbf{N}$ & Mean & Median & Std. Dev. \\
\hline All & 331 & 17.73 & 16 & 11.61 \\
\hline High $\mathrm{GO}^{(\mathbf{a})}$ & 86 & 16.29 & 13 & 8.97 \\
\hline Low $\mathrm{GO}^{(\mathbf{a})}$ & 134 & 16.75 & 16 & 10.79 \\
\hline
\end{tabular}

(a) High (Low) GO firms are defined as firms in the top (bottom) tercile of the 1,714 firm-year observations according to their MVA/BVA in 2006.

Panel C. Firm-specific RPE use estimated using the model from column 3 of Table 5

\begin{tabular}{|c|c|c|c|c|c|c|c|c|c|c|c|c|c|c|}
\hline & \multicolumn{4}{|c|}{ Sample firms for 2006-2008 } & \multicolumn{4}{|c|}{ "RPE disclosing firms } & \multicolumn{4}{|c|}{ "Non-RPE disclosing firms } & \multirow{2}{*}{\multicolumn{2}{|c|}{$\begin{array}{l}\text { RPE disclosing vs. non- } \\
\text { RPE disclosing firms } \\
P \text {-values of Difference in }\end{array}$}} \\
\hline & & & Estim & ted RPE & & & Estim & ted RPE & & & Estim & ted RPE & & \\
\hline & $\mathbf{N}$ & $\%$ & Mean & Median & $\mathbf{N}$ & $\%$ & Mean & Median & $\mathbf{N}$ & $\%$ & Mean & Median & Mean & Median \\
\hline All Firms & 3,335 & $100 \%$ & -0.33 & -0.40 & $486^{(\mathbf{b})}$ & $100 \%$ & -0.44 & -0.48 & 1,224 & $100 \%$ & -0.30 & -0.37 & 0.00 & 0.00 \\
\hline High $\mathrm{GO}^{(\mathbf{c})}$ & 1,111 & $33 \%$ & 0.02 & -0.12 & 128 & $26 \%$ & -0.17 & -0.24 & 454 & $37 \%$ & 0.02 & -0.10 & 0.00 & 0.00 \\
\hline Low $\mathrm{GO}^{(\mathrm{c})}$ & 1,112 & $33 \%$ & -0.58 & -0.57 & 189 & $39 \%$ & -0.60 & -0.60 & 360 & $29 \%$ & -0.58 & -0.55 & 0.48 & 0.13 \\
\hline
\end{tabular}

(b) The number of 486 RPE disclosing firms is smaller than the 489 from Panel A, because three observations drop out when merged into the paper's sample.

${ }^{\text {(c) }}$ High (low) GO firms are defined as firms in the top (bottom) tercile of the 3,335 firm-year observations according to their MVA/BVA in 2006. 